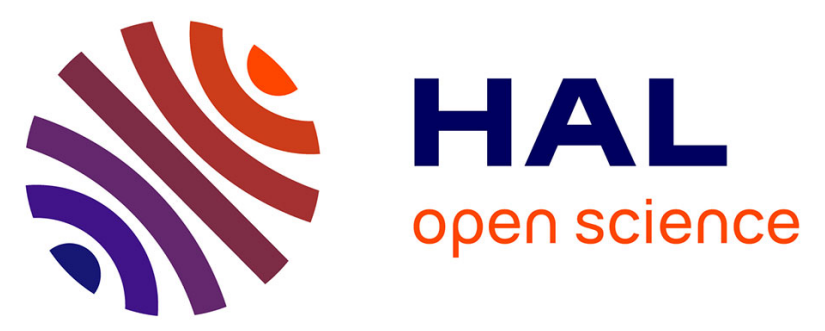

\title{
Pesticide mixture toxicity assessment through in situ and laboratory approaches using embryo-larval stages of the pacific oyster (Magallana gigas)
}

Eliška Kuchovská, Patrice Gonzalez, Lucie Bláhová, Mathilde Barré, Corentin

Gouffier, Jérôme Cachot, Alicia Roméro-Ramirez, Luděk Bláha, Bénédicte

Morin

\section{To cite this version:}

Eliška Kuchovská, Patrice Gonzalez, Lucie Bláhová, Mathilde Barré, Corentin Gouffier, et al.. Pesticide mixture toxicity assessment through in situ and laboratory approaches using embryo-larval stages of the pacific oyster (Magallana gigas). Marine Environmental Research, 2021, 169, pp.105390. 10.1016/j.marenvres.2021.105390 . hal-03434109

\author{
HAL Id: hal-03434109 \\ https://hal.science/hal-03434109
}

Submitted on 25 Nov 2021

HAL is a multi-disciplinary open access archive for the deposit and dissemination of scientific research documents, whether they are published or not. The documents may come from teaching and research institutions in France or abroad, or from public or private research centers.
L'archive ouverte pluridisciplinaire HAL, est destinée au dépôt et à la diffusion de documents scientifiques de niveau recherche, publiés ou non, émanant des établissements d'enseignement et de recherche français ou étrangers, des laboratoires publics ou privés. 
1 Pesticide mixture toxicity assessment through in situ and laboratory

2 approaches using embryo-larval stages of the Pacific oyster (Magallana 3 gigas)

4

5 Eliška Kuchovská ${ }^{1,2}$, Patrice Gonzalez ${ }^{2}$, Lucie Bláhová ${ }^{1}$, Mathilde Barré2, Corentin Gouffier ${ }^{2}$, 6 Jérôme Cachot ${ }^{2}$, Alicia Romero-Ramirez ${ }^{2}$, Luděk Bláha ${ }^{1}$, Bénédicte Morin ${ }^{23}$

7

81 Masaryk University, Faculty of Science, RECETOX, Kamenice 753/5, 62500 Brno, Czech 9 Republic

102 Univ. Bordeaux, CNRS, EPOC, EPHE, UMR 5805, F-33600 Pessac, France

113 Corresponding author: benedicte.morin@u-bordeaux.fr 


\section{Abstract}

15 Worsened state of oysters in French Arcachon Bay, demand an investigation of possible

16 causes. This study evaluated the effects of an environmentally relevant mixture of five

17 common pesticides on the early-life stages of the Pacific oyster (Magallana gigas).

18 Laboratory assays with artificial mixture and in situ transplantation were complementarily

19 used to investigate a series of sublethal endpoints. The laboratory exposure revealed

20 developmental toxicity at $0.32 \mu \mathrm{g} / \mathrm{L}$, which corresponds to mixture concentrations in

21 Arcachon Bay. Downregulation of some gene transcriptions was observed at environmental

22 level. No difference in larvae development was revealed among the three sites in Arcachon

23 Bay. This study was the first to evaluate locomotion of oyster larvae exposed in situ.

24 Suspected poor water quality in the inner part of Arcachon Bay was reflected by impairment

25 at the molecular level. In conclusion, current concentrations of the tested pesticides in

26 Arcachon Bay hinder larval development and affect several biological functions.

\section{KEYWORDS}

Arcachon Bay; Coastal waters; Developmental abnormality; Gene expression; In situ;

Mixtures; Pacific oyster; Pesticides; Sublethal effects; Swimming behavior 
- $1^{\text {st }}$ study to evaluate locomotion of oyster larvae exposed in situ

- Pesticide mixture even at low concentration is not safe for oyster development

- Water quality in Arcachon Bay is sufficient for development of well-formed larvae

- Effects on the gene expression were observed at realistic concentrations

- Larvae caged at sites with different pollution had variable gene expressions

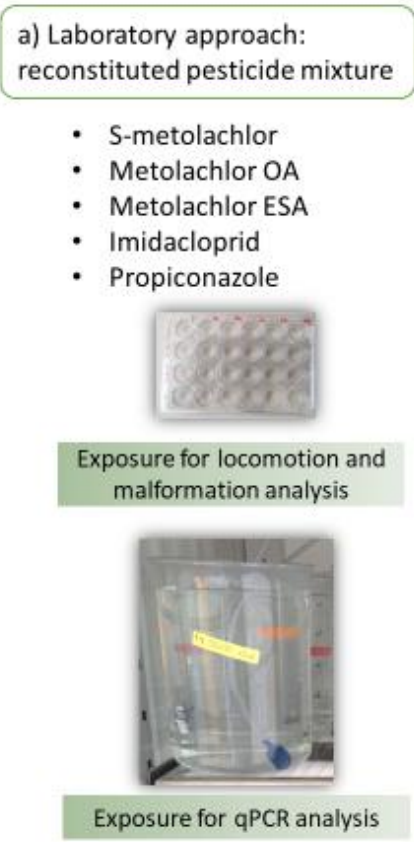

41

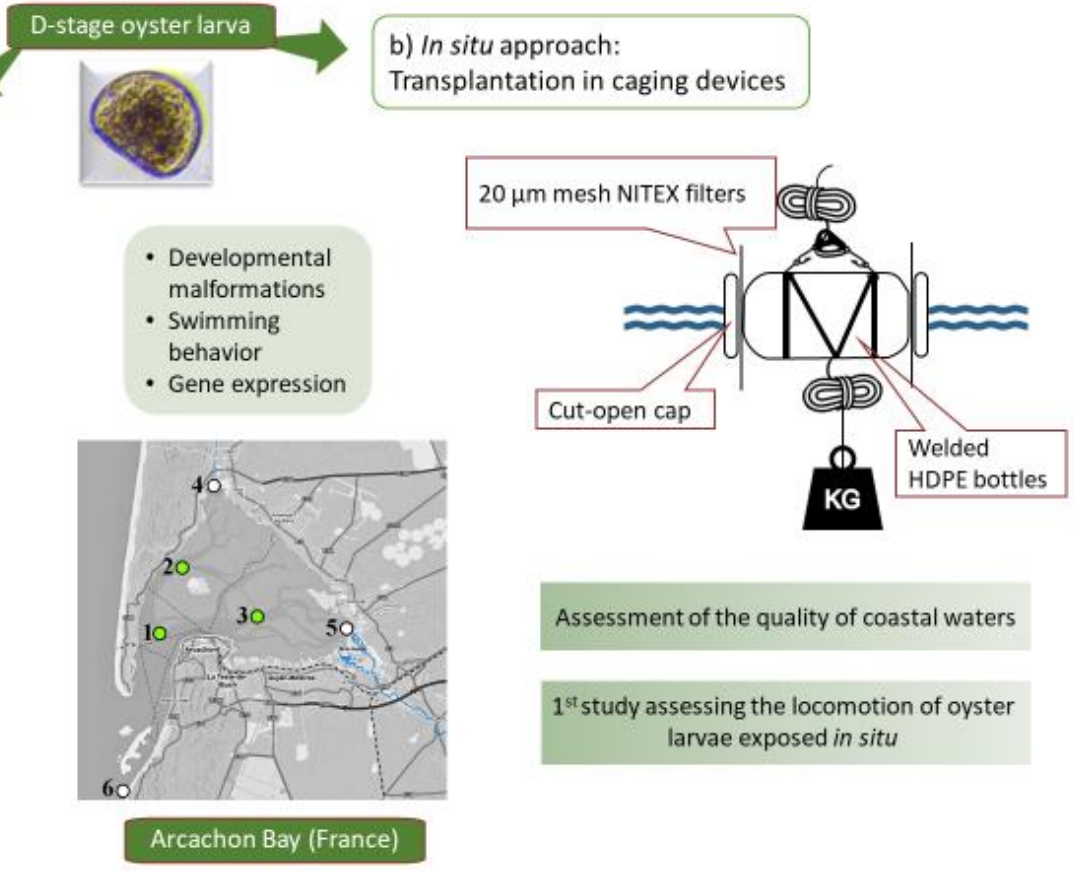




\section{Introduction}

Arcachon Bay is a semi-sheltered shallow lagoon $\left(174 \mathrm{~km}^{2}\right)$ on the Atlantic coastline in the South-west of France (Bertrand, 2014). The Pacific oyster (Magallana gigas, also known as Crassostrea gigas), an invasive species on the European coast introduced from the northwest Pacific Ocean (Troost, 2010), has become an emblematic and farmed species in Arcachon Bay. Several issues such as the decline in oyster recruitment and spat collection (Auby et al., 2014), decrease in the seagrass Zostera population (Auby et al., 2011; Cognat et al., 2018), and anomalies in the production of phytoplankton (Auby and Maurer, 2004) have been observed in Arcachon Bay during the last two decades. Possible causes of the oyster recruitment decline have been investigated, including the incidence of oyster herpes virus (Labbate et al., 2015) and the coupled effect of climate change and pesticide pollution (Gamain, 2016). However, the described issues have not been resolved and other causes are being searched for. Numerous hazardous substances are regularly detected in the lagoon by REMPAR, the survey network for monitoring of pesticides and micropollutants (https://www.siba-bassin-arcachon.fr/actions-environnementales/les-reseaux-de-surveillancerepar-et-rempar). Pesticides are brought into the Bay by lagoon tributaries, mainly by river Leyre (Tapie and Budzinski, 2018). While the impacts of individual pesticide compounds on non-target organisms are usually studied, we still lack information about the toxicity of environmentally relevant mixtures as also emphasized in the European Green Deal (European Commission, 2020). Mixtures can result in synergistic, antagonistic, or additive effects, as documented by Gustavsson et al. (2017) and Cedergreen (2014). For instance, neonicotinoids are known to exert addition or synergy effects when occurring in mixtures with some fungicides (Morrissey et al., 2015).

In Arcachon Bay, complex mixtures of tens of pesticides (out of a hundred molecules screened) are often detected (Tapie and Budzinski, 2018). According to this monitoring study, some of the most commonly found molecules in the waters of the lagoon are insecticide imidacloprid (IMI), fungicide propiconazole (PRO), and herbicide S-metolachlor (SM) with its two dominant metabolites metolachlor oxanilic acid (MOA) and metolachlor ethanesulfonic acid (MESA). IMI is a neurotoxic neonicotinoid banned in the EU, acting as an agonist on the post-synaptic nicotinic acetylcholine receptors (Matsuda et al., 2001). PRO is a triazole hindering the synthesis of fungal cell membranes by inhibiting the ergosterol formation (Oliver and Hewitt, 2014), and SM is a chloroacetanilide suppressing the plant 
growth by impairing the biosynthesis of very-long-chain fatty acids (Götz and Böger, 2004). Impact of imidacloprid on molluscs were recently thoroughly reviewed (Ewere et al., 2021). Effects of the mentioned individual compounds on the embryo-larval stages of the Pacific oyster were already assessed (Gamain et al., 2017, 2016; Kuchovská et al., 2021; Mai et al., 2014, 2013), and some of these were even present in a recent complex mixture of 14 pesticides toxicity evaluation (Mai et al., 2020).

Laboratory bioassays are one possible way to assess the effects of environmental mixtures of pollutants at relevant concentrations. However, more valuable insight is gained when laboratory bioassays are coupled with in situ caging experiments. Results obtained by this combined approach are ecologically relevant and reflect realistic and complex site-specific conditions. These conditions include not only the chemical exposure and tidal movements, weather conditions, temperature changes, or natural presence of microorganisms, which are all factors difficult to replicate in the laboratory (Ferrari et al., 2013). Overall, whereas laboratory bioassays discriminate which concentration of pesticides affect the oyster development, the in situ approach may reveal if the laboratory findings may be used to explain the real situation in the bay, if the effects observed by these two means are comparable, and, more importantly, the rate of succesful oyster development on different sites of the bay with different pollution backgrounds. A more complex picture of the issue of oyster development in Arcachon Bay is thus obtained. There is a long tradition of using bivalves (collected in the field or deployed via transplant caging) such as mussels or oysters for in situ coastal monitoring programs (Besse et al., 2012; Beyer et al., 2017). Moreover, an ASTM (American Society for Testing and Materials) guideline for field bivalve testing exists (ASTM, 2013). However, these monitoring studies use transplanted adult (rarely juvenile) oysters (Cao and Wang, 2016; Clara Rebouças Do Amaral et al., 2005; Hédouin et al., 2011; Jenny et al., 2016; Lee and Birch, 2016) or mussels (Benedicto et al., 2011; Brooks et al., 2012; Cappello et al., 2015; Devier et al., 2005; Haynes et al., 1995; Lehtonen et al., 2016). One of the rare studies not employing adult organisms was carried out with a six-week-old oyster spat in in situ microcosms (Stachowski-Haberkorn et al., 2008). To the best of our knowledge, only two biomonitoring studies (Geffard et al., 2001; Quiniou et al., 2007) used the embryo-larval stages of bivalves. The early life stages of bivalves have a high sensitivity to contaminants due to the body mass difference and naked body surface (Hutchinson et al., 1998; Beiras, 2018), quick development (D-larvae is formed after $24 \mathrm{~h}$ ), and a convenient high-throughput screening format. 
107 The present study aimed to investigate and compare the sublethal effects (developmental 108 malformations, neurobehavioral locomotion patterns, and gene expression levels) on Pacific

109

110 oyster larvae (Magallana gigas) in two complementary exposure conditions, i.e. i) laboratory exposure to an environmentally relevant reconstituted mixture of pesticides and ii) in situ transplantation in caging devices for two days on three different sites in Arcachon Bay. This study is the first to combine in situ and laboratory approaches with embryo-larval stages of Pacific oyster.

\section{Materials and methods}

\subsection{Chemicals and reference seawater handling}

Imidacloprid (IMI, CAS 138261-41-3, Pestanal, purity $100 \%$ ), propiconazole (PRO, CAS 60207-90-1, Pestanal, purity $100 \%$ ), S-metolachlor (SM, CAS 87392-12-9, Pestanal, purity $\geq 98.0 \%$ ), metolachlor oxanilic acid (MOA, CAS 152019-73-3, Pestanal, purity $\geq 98.0 \%$ ), metolachlor ethanesulfonic acid (MESA, CAS 947601-85-6, Pestanal, purity $\geq 95.0 \%$ ), and $\mathrm{CuSO}_{4}$ were purchased from Sigma-Aldrich. Concerning gene expression analysis, primers were purchased from Sigma proligo, RNA later buffer was purchased from Qiagen, and phenol and chloroform Rectapur ${ }^{\circledR}$ were purchased from Sigma. Copper solution (stock solution of $100 \mathrm{mg} / \mathrm{L}$ in milliQ water) was used as a positive control in laboratory experiments and was stored at $5{ }^{\circ} \mathrm{C}$, as well as PRO solution, which was prepared in DMSO (5 g/L) and other pesticide solutions (SM, IMI, MOA, MESA) which were prepared in milliQ water $(50 \mathrm{mg} / \mathrm{L})$. Dilutions in final exposure solutions were carried out using reference seawater collected at beach Petit Nice (approx. 44 $33^{\prime} 40.3^{\prime \prime} \mathrm{N} 1^{\circ} 14^{\prime} 27.1^{\prime \prime} \mathrm{W}$ ). Seawater was transported in $10 \mathrm{~L}$ plastic containers, filtered at $0.22 \mu \mathrm{m}$, and passed through UV light to eliminate microorganisms. Filtered seawater (FSW) was stored at $5{ }^{\circ} \mathrm{C}$ in the dark and was used usually within a few days. Few hours before the experimentations, FSW was filtered again at $0.22 \mu \mathrm{m}$. The background concentration of pesticides in FSW was measured by LC-MS/MS (cf. section 2.6).

\subsection{Embryo-larval test: a laboratory approach}

Five couples of mature pacific oysters (Magallana gigas, also called Crassostrea gigas (Bayne et al., 2017)) were obtained from Guernesey Sea Farm hatchery (Guernesey, UK). Oysters were immediately used on the day of the arrival or they were kept in oxygenated FSW at $11^{\circ} \mathrm{C}$ for $24 \mathrm{~h}$. A detailed version of the used method for oyster spawning (alternating 
thermal shocks) is described in Kuchovská et al. (2021) and Gamain et al. (2016) and follows

140 the French guideline (NF ISO 17244, 2015). Because not all the oysters did spawn, multiple

141 shipments of oysters were needed during the years 2018 and 2019. Obtained embryos were

142 then incubated in experimental units (vessel type is depending on the measured endpoint as

143 described below) at $24{ }^{\circ} \mathrm{C}$ in the dark until they reached the developmental stage of D-larva.

144 After the exposures, developmental malformations, locomotion (section 2.4), and gene

145 expression analyses (section 2.5) were carried out. To assess the developmental

146 malformations, an embryo-larval test was carried out according to the French guideline (NF

147 ISO 17244, 2015) in 24-well microplates (Greiner Bio-One, Cellstar).The microplates were

148 precoated $24 \mathrm{~h}$ before the test with the corresponding concentration of mixture solution due to

149 propiconazole hydrophobicity, as confirmed by chemical analyses during our previous study

150 (Kuchovská et al., 2021). Embryos from one oyster couple were considered as one

151 independent experiment; each oyster couple formed 4 analytical replicates (wells) per

152 concentration in the microplates with approximately $225 \pm 10 \%$ embryos per well. Seven

153 oyster couples per condition were used for the assessment of developmental malformations.

154 Negative control (FSW) and solvent control (0.016 \% DMSO) were present on every

155 microplate. The embryos were exposed to increasing concentrations of the pesticide mixture

156 (MIX) composed of IMI, PRO, SM, MOA, and MESA (total concentration of five pesticides

157 corresponding to $0.32 \mu \mathrm{g} / \mathrm{L}, 1.6 \mu \mathrm{g} / \mathrm{L}, 8 \mu \mathrm{g} / \mathrm{L}, 40 \mu \mathrm{g} / \mathrm{L}, 200 \mu \mathrm{g} / \mathrm{L}, 1 \mathrm{mg} / \mathrm{L}, 5 \mathrm{mg} / \mathrm{L}, 25 \mathrm{mg} / \mathrm{L}$;

158 individual concentrations are listed in Table 1).

159 Table 1 Concentrations of different pesticides in the reconstituted mixture used to expose 160 embryos of oyster Magallana gigas.

\begin{tabular}{ccccccc} 
Code & PRO & IMI & SM & MOA & MESA & $\begin{array}{c}\text { Total } \\
\text { concentration }\end{array}$ \\
\hline C1 & $10 \mathrm{ng} / \mathrm{L}$ & $100 \mathrm{ng} / \mathrm{L}$ & $10 \mathrm{ng} / \mathrm{L}$ & $100 \mathrm{ng} / \mathrm{L}$ & $100 \mathrm{ng} / \mathrm{L}$ & $0.32 \mu \mathrm{g} / \mathrm{L}$ \\
C2 & $50 \mathrm{ng} / \mathrm{L}$ & $500 \mathrm{ng} / \mathrm{L}$ & $50 \mathrm{ng} / \mathrm{L}$ & $500 \mathrm{ng} / \mathrm{L}$ & $500 \mathrm{ng} / \mathrm{L}$ & $1.6 \mu \mathrm{g} / \mathrm{L}$ \\
C3 & $0.25 \mu \mathrm{g} / \mathrm{L}$ & $2.5 \mu \mathrm{g} / \mathrm{L}$ & $0.25 \mu \mathrm{g} / \mathrm{L}$ & $2.5 \mu \mathrm{g} / \mathrm{L}$ & $2.5 \mu \mathrm{g} / \mathrm{L}$ & $8 \mu \mathrm{g} / \mathrm{L}$ \\
C4 & $1.25 \mu \mathrm{g} / \mathrm{L}$ & $12.5 \mu \mathrm{g} / \mathrm{L}$ & $1.25 \mu \mathrm{g} / \mathrm{L}$ & $12.5 \mu \mathrm{g} / \mathrm{L}$ & $12.5 \mu \mathrm{g} / \mathrm{L}$ & $40 \mu \mathrm{g} / \mathrm{L}$ \\
C5 & $6.25 \mu \mathrm{g} / \mathrm{L}$ & $62.5 \mu \mathrm{g} / \mathrm{L}$ & $6.25 \mu \mathrm{g} / \mathrm{L}$ & $62.5 \mu \mathrm{g} / \mathrm{L}$ & $62.5 \mu \mathrm{g} / \mathrm{L}$ & $200 \mu \mathrm{g} / \mathrm{L}$ \\
C6 & $31.25 \mu \mathrm{g} / \mathrm{L}$ & $312.5 \mu \mathrm{g} / \mathrm{L}$ & $31.25 \mu \mathrm{g} / \mathrm{L}$ & $312.5 \mu \mathrm{g} / \mathrm{L}$ & $312.5 \mu \mathrm{g} / \mathrm{L}$ & $1 \mathrm{mg} / \mathrm{L}$ \\
C7 & $156.25 \mu \mathrm{g} / \mathrm{L}$ & $1.563 \mathrm{mg} / \mathrm{L}$ & $156.25 \mu \mathrm{g} / \mathrm{L}$ & $1.563 \mathrm{mg} / \mathrm{L}$ & $1.563 \mathrm{mg} / \mathrm{L}$ & $5 \mathrm{mg} / \mathrm{L}$ \\
C8 & $781.25 \mu \mathrm{g} / \mathrm{L}$ & $7.825 \mathrm{mg} / \mathrm{L}$ & $781.25 \mu \mathrm{g} / \mathrm{L}$ & $7.825 \mathrm{mg} / \mathrm{L}$ & $7.825 \mathrm{mg} / \mathrm{L}$ & $25 \mathrm{mg} / \mathrm{L}$
\end{tabular}


162 The lowest used concentration $(\mathrm{C} 1)$ is reflecting the usual concentrations often measured in

163 Arcachon Bay in France (cf. Supplementary Table S1). Concentration C2 approximately

164 corresponds to the highest concentrations measured in Arcachon Bay. The treatments C3 and

$165 \mathrm{C} 4$ may be considered as maximal environmental concentrations measured in the surface

166 waters in the world (Table 2). Higher concentrations (C5-C8) were used to allow for

167 estimation of the $\mathrm{EC}_{50}$ or as a prediction of acute peak contamination periods.

168

169 Table 2 Detected concentrations of pesticides of interest in surface waters in various locations 170 in the world.

\begin{tabular}{l|cc} 
Substance & \multicolumn{2}{|c}{ Detected concentration } \\
\hline \multirow{2}{*}{ Propiconazole } & $0.7 \mu \mathrm{g} / \mathrm{L}$ Vietnam & $0.81 \mu \mathrm{g} / \mathrm{L}$ China \\
& $($ Toan et al., 2013) & (Peng et al., 2018) \\
Imidacloprid & $3.29 \mu \mathrm{g} / \mathrm{L}$ California (USA) & $320 \mu \mathrm{g} / \mathrm{L}$ Netherlands \\
& $($ Starner and Goh, 2012) & $($ Van Dijk et al., 2013) \\
Metolachlor & $10.5 \mu \mathrm{g} / \mathrm{L}$ South Georgia (USA) & $16.5 \mu \mathrm{g} / \mathrm{L}$ Italy \\
& $($ Glinski et al., 2018) & (Meffe and de Bustamante, 2014) \\
MOA & $1.21 \mu \mathrm{g} / \mathrm{L}$ Mississippi River Basin & $5.3 \mu \mathrm{g} / \mathrm{L}$ Iowa (USA) \\
& (Rebich et al., 2004) & $($ Kalkhoff et al., 2012) \\
MESA & $2.51 \mu \mathrm{g} / \mathrm{L}$ Mississippi River Basin & $10.3 \mu \mathrm{g} / \mathrm{L}$ Iowa (USA) \\
& (Rebich et al., 2004) & $($ Kalkhoff et al., 2012)
\end{tabular}

171

172 After the incubation of embryos $\left(24 \mathrm{~h}\right.$ at $\left.24{ }^{\circ} \mathrm{C}\right)$ exposed to the mentioned concentrations, the 173 microplates were used for the non-invasive video capture (cf. 2.4 Locomotion analysis). After 174 the video capture (at approximately $30 \mathrm{~h}$ ), formaldehyde ( $25 \mu \mathrm{L}$ at $37 \%$ ) was added to every 175 well (final volume $2025 \mu \mathrm{L}$ ) to stabilize the larvae state for the developmental malformation 176 analysis. The microplates were kept at $4{ }^{\circ} \mathrm{C}$ in the dark. An inverted microscope (Nikon 177 Eclipse TS100) was used to assess different forms of developmental malformations in 178100 embryos per well, i.e. mantle malformation, scalloped shell malformation, concave shell 179 malformation, developmental arrest. Photos of different malformations, as well as well180 formed larvae, are published in Kuchovská et al. (2021) in Figure 1. According to the ISO 
norm (NF ISO 17244, 2015), the malformation rate in the negative control cannot exceed $20 \%$ and the $\mathrm{EC}_{50}$ for abnormal larvae exposed to $\mathrm{Cu}^{++}$should be between 6 and $16 \mu \mathrm{g} / \mathrm{L}$.

\section{$183 \quad 2.3$ In situ approach}

184 Three sites were chosen for the in situ study. The reference site "Grand Banc" (GB) is located 185 in Teychan channel $\left(44^{\circ} 39,914 \mathrm{~N} ; 001^{\circ} 13,076 \mathrm{~W}\right)$ near the mouth of Arcachon Bay. The 186 Passes is a narrow $(2-3 \mathrm{~km})$ but long $(12 \mathrm{~km})$ channel connecting Arcachon Bay with the Bay 187 of Biscay. Therefore, water quality (concerning pesticides) at GB is in a relatively good state 188 as monitored in years 2010-2016 (Tapie and Budzinski, 2018). The two other sites are 189 situated in the inner part of Arcachon Bay, thus undergoing higher anthropogenic pressure: 190 "Les Jacquets" (J) and "Comprian" (C) are in channel Chenal de l'Île (44 42, 831 N; $001^{\circ} 11$, $191235 \mathrm{~W}$ ) and Teychan channel (44 40, $833 \mathrm{~N}$; 001 07, $096 \mathrm{~W})$, respectively. The location of 192 the sites is shown in Figure 1A.

193 Adult oysters producing embryos for the in situ caging approach were purchased from France 194 Naissain (Bouin, France). The spawning of the mature oysters was carried out in the same 195 manner as for the laboratory approach (cf. section 2.2). Obtained embryos were transported to

196 the three selected sites (Figure 1A) in FSW and the caging devices were deployed at the site 197 approximately at $2 \mathrm{hpf}$ (hours post fertilization) using a quick small boat. The device was 198 inspired by the caging device of Geffard et al. (2001) and was made of two welded 4 L HDPE 199 bottles with open caps at each side (Figure 1B). Both caps were holding a $20 \mu \mathrm{m}$ mesh filter 200 (SEFAR NITEX®) to let the water freely circulate. Devices were held under the water surface 201 using a weight and were attached to a buoy with a rope (approximately 2 meters long to keep 202 the device underwater surface even at low tide). Four devices containing approximately 203666,000 embryos from four mature oyster couples were deployed at each of the three sites. 204 Before adding the embryos to the device, water from the site was slowly poured into the 205 device through the $20 \mu \mathrm{m}$ mesh filter to keep the water in the device clean from larger debris 206 that would have corrupted the ulterior locomotion analysis. The transplantation was carried 207 out on the $24^{\text {th }}$ July 2019 between $11 \mathrm{~h}$ and $13 \mathrm{~h} 15$ local time (summertime is the period of 208 oyster reproduction in Arcachon Bay). Underwater view of used devices is attached to this 209 research paper. The water temperature in the waters of Arcachon Bay oscillated during the 210 experimentation approximately between 19 and $24{ }^{\circ} \mathrm{C}$ as measured $1.5 \mathrm{~m}$ under the water 211 surface at Comprian site and buoy 13 (temperature data obtained from SOMLIT database at 212 somlit.fr). Although the exposure during the laboratory approach lasted 1 day, the exposure in 213 the field was prolonged to 2 days to ensure the successful development of D-larva. Indeed, the 
constant temperature of $24{ }^{\circ} \mathrm{C}$ kept in the laboratory is ideal for the development of D-larva.

215 However, in the field, the embryos are subjected to varying temperatures, often below the $24{ }^{\circ} \mathrm{C}$ which slow the development. After being deployed two days (approx. 46 hours) in the

217 field, the devices were transported in beakers into the laboratory and the larvae were gently 218 collected on a $20 \mu \mathrm{m}$ mesh and transferred into 24-well microplates in the approximate 219 concentration of 225 embryos per well ( 4 replicates per caging device) to perform the video 220 capture (section 2.4) followed by formaldehyde stabilization (as in the laboratory approach), and ulterior developmental malformation analysis. The rest of the larvae was collected in a polypropylene microtube for the gene expression analysis (section 2.5).

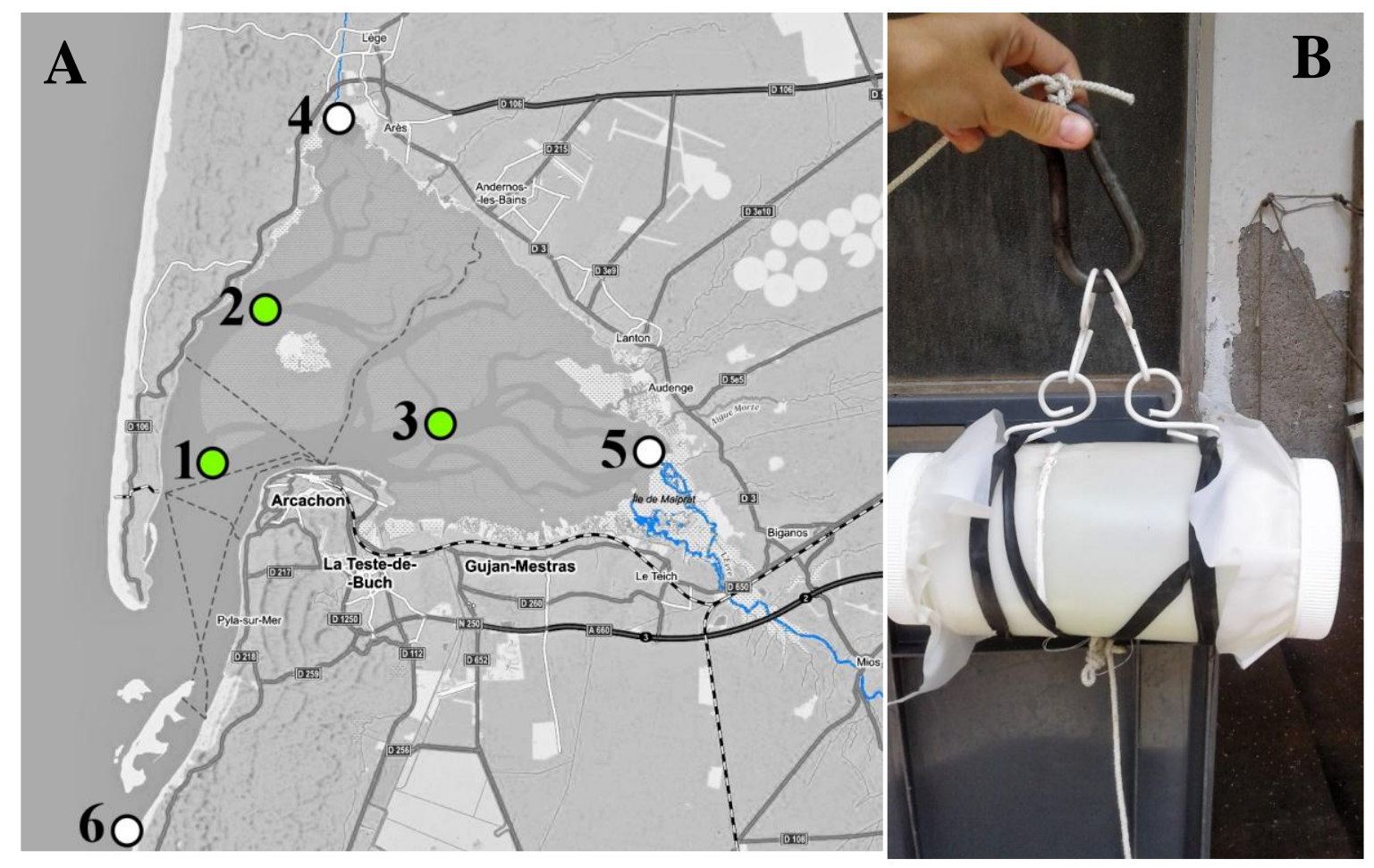

224 Figure 1 A Map of Arcachon Bay (France) with selected sites for the field transplantation experiment and other important points: 1 Site Grand Banc (GB); 2 Site Les Jacquets (J); 3

226 Site Comprian (C); 4 Mouth of the river Canal des Étangs; 5 Mouth of the river Leyre; 6 227 Beach Petit Nice - sampling point of the reference seawater. B Photo of the caging device. 228 (Map modified from mapy.cz)

\subsection{Locomotion analysis}

230 In the laboratory approach, oyster embryos were exposed to three environmentally relevant 231 concentrations of the pesticide mixture (total nominal concentrations of five pesticides $2320.32 \mu \mathrm{g} / \mathrm{L}, 1.6 \mu \mathrm{g} / \mathrm{L}$, and $8 \mu \mathrm{g} / \mathrm{L}$; for individual concentrations cf. Table 1) for $24 \mathrm{~h}$ in the dark 233 in 24-well microplates (Greiner Bio-One, Cellstar; 225 embryos per well). In the in situ 
approach, oyster larvae were gently collected at the end of the experiment (48 h) on a $20 \mu \mathrm{m}$ mesh and transferred into 24-well microplates in the approximately same concentration of embryos per well (4 replicates per caging device). 2 min video of each well was taken at zoom 40x using an inverted microscope Nikon Eclipse TS100 equipped with camera Nikon DS-Fi2, and software NIS Element. The temperature of solutions in the microplates was kept at $24{ }^{\circ} \mathrm{C}$ all the time for both experimental approaches. The detailed method (including conversion of videos by VirtualDub and their analysis by ImageJ) is described in Gamain et al. (2019). At the end of the ImageJ analysis, the maximal and average swimming speed, and trajectory type (rectilinear, circular, and stationary) of each larva are determined. Graphical representation of different types of trajectory paths is published in Kuchovská et al. (2021) in

244 Figure 2.

\subsection{Gene expression analysis}

246 Oyster embryo laboratory exposure for gene expression analysis is described in detail in 247 Kuchovská et al. (2021). In brief, half of the million embryos issued from one oyster mature couple were incubated in three-liter glass beakers at $24^{\circ} \mathrm{C}$ in the dark for $42 \mathrm{~h}$ (it was not possible to expose the organisms for 48 hours because the handling of larvae would have to

250 be done during the night) with an oxygenation system (plastic tube with an aquarium air 251 stone). The total pesticide exposure concentrations were $0.32 \mu \mathrm{g} / \mathrm{L}, 1.6 \mu \mathrm{g} / \mathrm{L}$, and $8 \mu \mathrm{g} / \mathrm{L}$ (for concentrations of individual compounds cf. Table 1). Larvae samples from the laboratory exposure in glass beakers and the in situ caging devices were collected on a $20 \mu \mathrm{m}$ mesh (SEFAR NITEX®) and distributed in five replicates containing 30,000 larvae each. The samples were stored in RNA later at $-80{ }^{\circ} \mathrm{C}$ until RNA extraction.

256 The RNA extraction, transcription, and qPCR analyses were carried out as described previously (Kuchovská et al., 2021). Briefly, SV Total RNA Isolation System Kit, Reverse Transcription System kit, and GoTaq ${ }^{\circledR}$ qPCR Master Mix kit (Promega) were used. The purity of all isolated RNA samples at 260/280 nm was between 2.14 and 2.18. Primer-pairs efficiency was checked beforehand (> $95 \%$ ). qPCR was carried out using the LightCycler480 (Roche). Results are expressed as fold changes of the exposed group compared to the control group (laboratory tests) or sampling site compared to the site Grand Banc (in situ tests).

Three reference genes ( $\beta$-actin, efl $\alpha$, and $r p l 7$ ) and fourteen genes of interest were used in the analysis. Genes of interest were implicated in mitochondrial metabolism (12S, coxl), regulation of the cell cycle/apoptosis (p53), oxidative stress defense (cat, sodMn, sodCu/Zn, 
$g p x)$, metal regulation $(m t 1, m t 2)$, apoptosis (bax, casp3), biotransformation (cypla), growth arrest and DNA damage repair (gadd45, rad51). Sequences, references, and accession numbers of all genes can be found in Kuchovská et al. (2021).

\subsection{Chemical analysis and water quality}

270 Dissolved oxygen, $\mathrm{pH}$, and salinity were measured in the experimental units for gene expression (laboratory approach) at the beginning and the end of the laboratory experiments, using a probe Multi 340i (WTW). All checked parameters complied with the revised norm by Leverett and Thain (2013). In brief, oxygen saturation varied between $91.6 \%$ and $98.2 \%$ (on average $95.0 \%$ and $93.8 \%$ respectively at the beginning and the end of the test); $\mathrm{pH}$ values oscillated between 7.96 and 8.2; salinity ranged from 34.2 to 35.7 psu (on average 35.0 psu).

Salinity in the in situ samples varied greatly, depending on the location of the sampling site and tide level. Samples from GB had salinity 28.8 and 34.6 psu at the beginning and the end of the experiments, respectively, samples from $\mathrm{J}$ site 22.4 and $23.5 \mathrm{psu}$, and samples from $\mathrm{C}$ site 17.1 and 18.7 psu. The tidal coefficient at the city of Arcachon was low: 50 on the first day and 41 on the last of the experiment.

281 LC-MS/MS was used to measure the concentrations of pesticides of interest. Samples of the in situ experiment were taken under the water surface (approx. $40 \mathrm{~cm}$ ) at each sampling point at the beginning and the end of the in situ experiment and transferred in glass bottles using a sampling stick. Calibration solutions and all samples were spiked with $10 \mu \mathrm{L}$ of the internal standard of tebuconazole D6 and imidacloprid D4 (both dissolved in $50 \%$ methanol) and stored at $-20^{\circ} \mathrm{C}$. The samples $(50 \mathrm{~mL}$ each) were lyophilized using a freeze dryer Alpha 2-4 LD Plus (Martin Christ Freeze Dryers). The samples were then dissolved in $3 \mathrm{~mL}$ of $100 \%$ acetonitrile and processed as described in Kuchovská et al. (2021). The quantification of analytes was based on the external calibration $(0.01-50 \mu \mathrm{g} / \mathrm{L}$ in $20 \%$ of acetonitrile $)$ and normalized with internal deuterium-labeled standards (imidacloprid D4 and tebuconazole D6). The limits of quantification (LOQ; $\mathrm{S} / \mathrm{N}>10$ ) in the samples for LC-MS/MS for IMI, PRO, SM, MOA, and MESA were $0.05,0.01,0.01,0.1$, and $0.1 \mu \mathrm{g} / \mathrm{L}$, respectively. However, the samples were concentrated 33 times, thus the concentrations of in situ samples ultimately quantifiable (LOQ) were 1.5, 0.3, 0.3, 3.0, and $3.0 \mathrm{ng} / \mathrm{L}$, for IMI, PRO, SM, MOA, and

296 Copper concentration was measured in positive control spiked samples (ICP-OES), and in the 297 in situ samples (ICP-MS). The in situ seawater samples $(100 \mathrm{~mL})$ were taken with a sampling 
stick with a plastic vial at the end of the exposure and carefully filtered through a filter into plastic falcons (all the material was beforehand cleaned with acid and was rinsed three times with seawater at the sampling point). The samples were then acidified with $5 \%$ final concentration of nitric acid in each sample and stored in the dark at $5{ }^{\circ} \mathrm{C}$.

302

303

304

305

\subsection{Data analysis}

Total malformed larvae (p) i.e. the sum of mantle malformation, shell malformation, and developmental arrest; and type of larval trajectory (p) were transformed using the arcsine transformation $\mathrm{p}^{\prime}=\arcsin \sqrt{\frac{p}{100}}$ (Sokal and Rohlf, 2012) before the statistical analysis ( $\mathrm{p}$ is expressed in \%). Because of the high variability of different test repetitions of larvae swimming speed data, the values $(\mu \mathrm{m} / \mathrm{sec}$ ) were normalized to the control (each replicate was divided by the average of four control replicates of the respective independent test repetition) before the statistical analysis. Gene expression results $\left(2^{-\Delta \Delta C T}\right)$ were first $\log$ normalized. All data are shown with standard deviations $( \pm \mathrm{SD})$ and corresponding numbers of independent values $(\mathrm{N}$; indicated at each results presentation).

All pre-treated data were then compared using Statistica 13.3 (StatSoft, USA). Data were controlled for normality (Shapiro-Wilk test; P > 0.01) and homoscedasticity (Levene test; $\mathrm{P}>0.05)$. If confirmed, ANOVA $(\mathrm{P}<0.05)$ followed by Tukey post-hoc test was used. In the other case, a non-parametric Kruskal-Wallis ( $<$ 0.05) with Mann-Whitney post-hoc test was carried out. $\mathrm{EC}_{50}$ was calculated using nonlinear logarithmic regression of the nominal concentration-response curves, using Graph Pad Prism 5 (Graph Pad Software, USA).

\section{Results}

\subsection{Chemical analysis}

Pesticide and copper concentrations measured in the in situ samples are shown in Table 3. All pesticide concentrations were found below a hundred ng/L except for SM at the Comprian site. Copper concentration at all sites was low and unlikely to cause any substantial developmental malformations. 
325 Table 3 Measured concentrations of selected pesticides (and metabolites) and copper at three 326 different sites of Arcachon Bay (GB: Grand Banc, J: Les Jacquets, C: Comprian) at the time 327 of transplanting of the oyster embryos in the field and at the end of the exposure; LOD $328($ MOA, MESA $)=1.5 \mathrm{ng} / \mathrm{L}$.

$\mathrm{ng} / \mathrm{L} \quad \mu \mathrm{g} / \mathrm{L}$

\begin{tabular}{cccccccc} 
Site & $\begin{array}{c}\text { Sampling } \\
\text { time (h) }\end{array}$ & PRO & IMI & SM & MOA & MESA & Cu \\
\hline \multirow{2}{*}{ GB } & 0 & 6.30 & 26.96 & 72.59 & <LOD & $<$ LOD & 0.59 \\
& 48 & 5.67 & 9.14 & 72.54 & $<$ LOD & 37.17 & 0.54 \\
\hline \multirow{2}{*}{ J } & 0 & 12.69 & 14.63 & 97.20 & $<$ LOD & $<$ LOD & 0.42 \\
& 48 & 8.73 & 10.08 & 92.75 & $<$ LOD & 54.54 & 0.79 \\
\hline \multirow{2}{*}{ C } & 0 & 9.27 & 10.89 & 119.79 & $<$ LOD & $<$ LOD & 0.65 \\
& 48 & 16.74 & 16.83 & 138.29 & $<$ LOD & 26.01 & 0.49
\end{tabular}

329 The stability of used compounds in seawater was verified in previous studies. Imidacloprid 330 and propiconazole (with precoating) were perfectly stable in microplates used for the embryo331 larval exposures. Imidacloprid was also stable in gene expression 3-liter beakers, however, 332 propiconazole concentrations slightly varied due to the impossibility to precoat the beakers 333 (Kuchovská et al., 2021). Metolachlor was also stable in seawater as shown by Gamain et al. 334 (2016).

\section{$335 \quad 3.2$ Embryo-larval development and observed malformations}

336 Positive control $\left(\mathrm{Cu}^{2+}\right)$ in the embryo-larval test revealed oyster sensitivity with $\mathrm{EC}_{50}$ of $3379.76 \pm 1.58 \mu \mathrm{g} / \mathrm{L}$ which corresponds to the value range $(6-16 \mu \mathrm{g} / \mathrm{L})$ preconized by the norm 338 (NF ISO 17244, 2015). Proportions of different larvae abnormalities caused by pesticide 339 mixture in the laboratory approach and by water in Arcachon Bay in the in situ experiment are 340 presented in Figure 2. 
a) Pesticide mixture

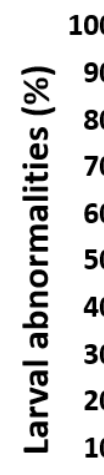

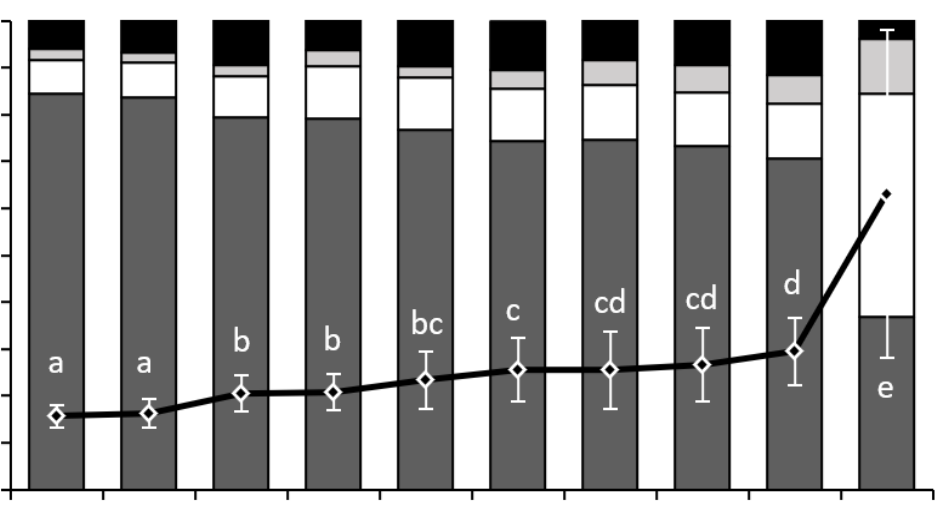

b) In situ exposure
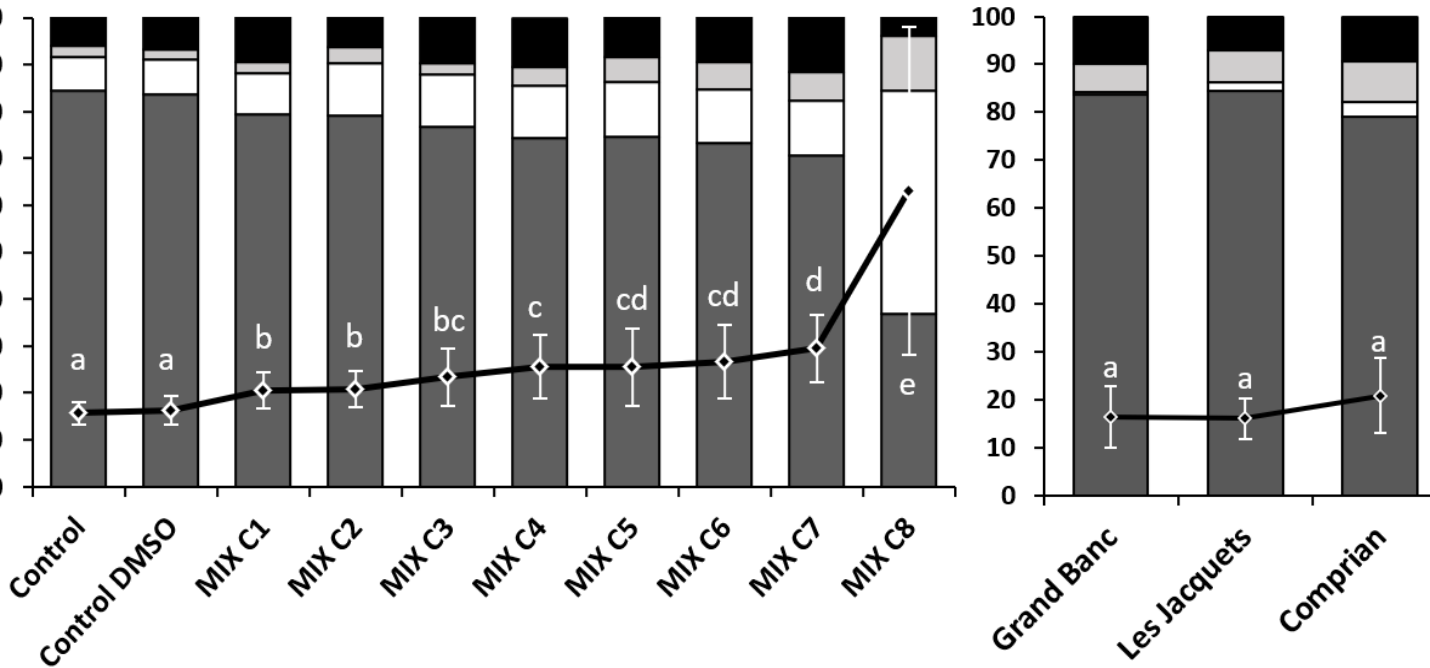

Developmental arrest

$\square$ Shell malformation

Well-formed $\square$ Mantle malformation -•-Sum of abnormal larvae

Figure 2 Larval abnormalities and the sum of affected oyster larvae a) after 30 hours of exposure to increasing concentrations of the MIX (individual concentrations of individual chemicals are shown in Table 1) and b) deployed in cages for two days in situ on three different sites of Arcachon Bay. Different letters indicate statistical differences between variables $(P<0.05)$. Results are presented as the mean $( \pm S D)$ of 7 independent experiments in the case of pesticide mixture and 4 in the case of in situ caging.

High variability in the sum of abnormal larvae caused by the highest concentration of the MIX in the laboratory mixture experiment was possibly due to the fact that 4 experiments were carried out in 2018 and 3 in 2019 . The sensitivity to the positive control $\left(\mathrm{EC}_{50}\right)$ was, however, in the correct value range as preconized by the ISO norm (NF ISO 17244, 2015) for both years $(11.81 \pm 1.18 \mu \mathrm{g} / \mathrm{L}$ and $8.80 \pm 1.25 \mu \mathrm{g} / \mathrm{L}$ in 2018 and 2019 , respectively). The sum of abnormal larvae served for the calculation of NOEC $(<0.32 \mu \mathrm{g} / \mathrm{L}), \operatorname{LOEC}(0.32 \mu \mathrm{g} / \mathrm{L})$, and $\mathrm{EC}_{50}(10.70 \pm 1.32 \mathrm{mg} / \mathrm{L})$ of the pesticide mixture (concentrations are expressed as the sum of nominal concentrations of the 5 pesticides). Even the lowest tested concentration of the pesticide mixture induced a significant increase of abnormal larvae $(20.61 \pm 3.84 \%)$ from controls $(15.66 \pm 2.28 \%$ and $16.38 \pm 3.08 \%$ of abnormal larvae in control FSW and DMSO control, respectively). On the other hand, no difference was observed between the three sites in Arcachon Bay.

\subsection{Behavioral analysis}


361 The behavioral assessment comprised different trajectory paths used by the oyster larvae and 362 their maximal and average swimming speeds. The results are shown in Figure 3. Absolute 363 values of the larvae exposed in situ swimming speed are shown in Supplementary Table S2.

364 No differences were observed after the laboratory exposure to the mixture of pesticides, 365 neither between the different sites in Arcachon Bay. However, a general decrease of 366 rectilinear trajectories may be observed at all in situ sites compared to the results obtained in 367 the laboratory.

a) Pesticide mixture
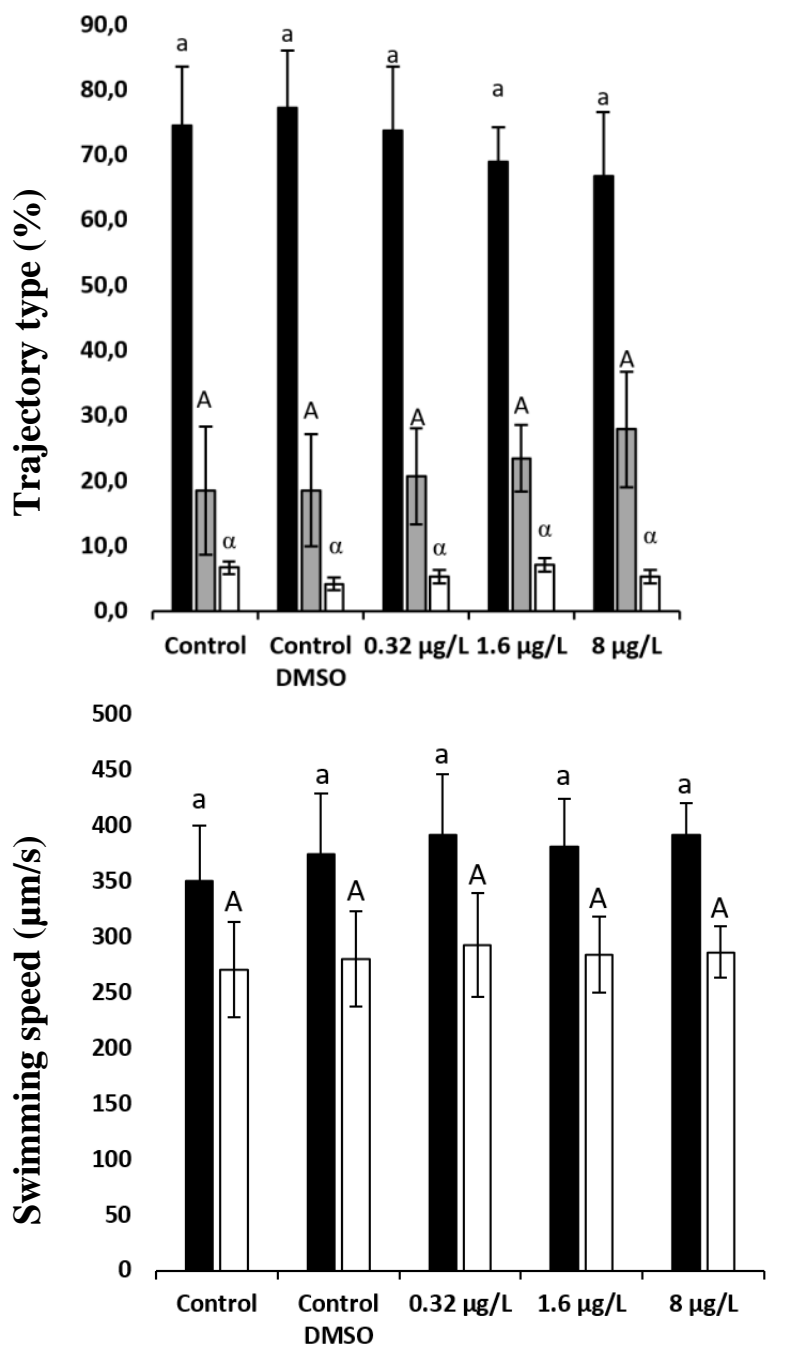

b) In situ exposure
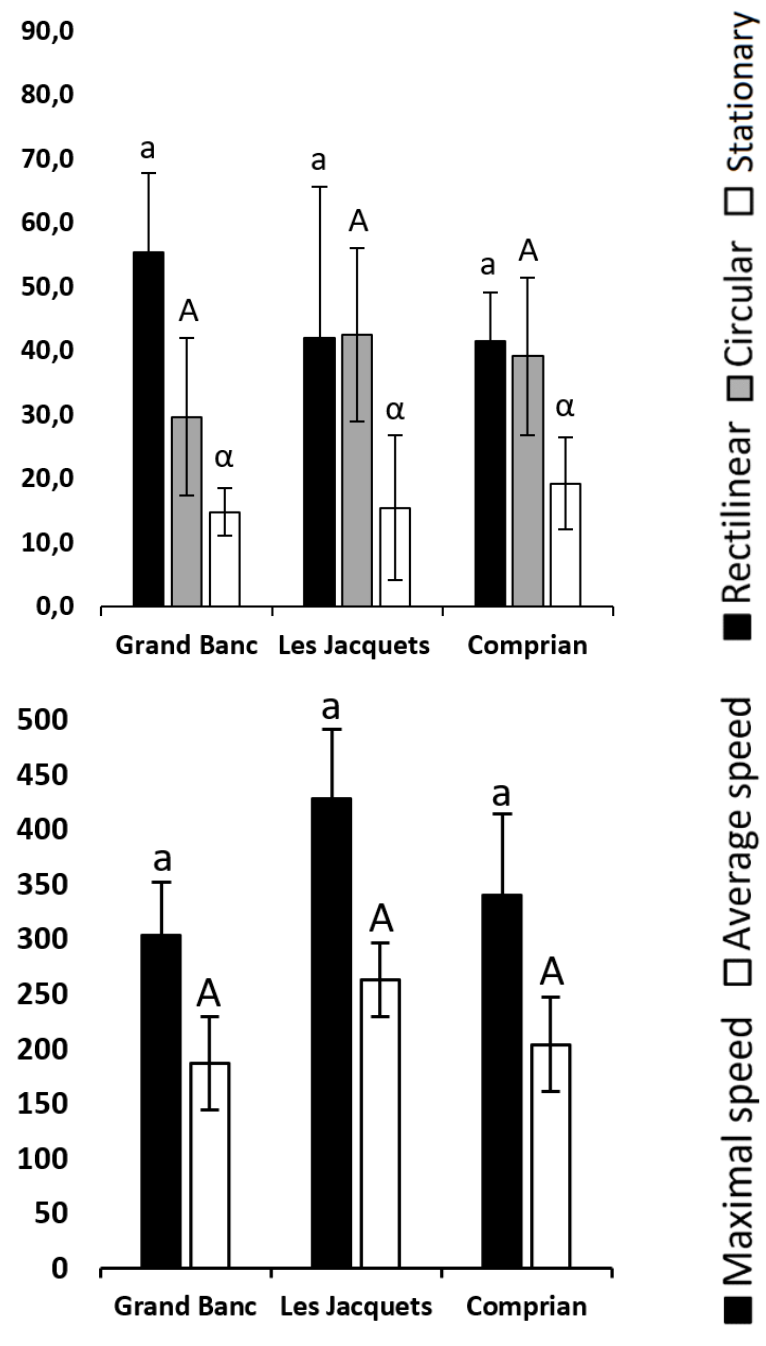

370 Figure 3 Trajectory types (\%; upper graphs) and swimming speed ( $\mu \mathrm{m} / \mathrm{s}$; lower graphs)

371 observed in oyster larvae a) after $24 \mathrm{~h}$ exposure to three concentrations of the MIX 372 (concentrations of individual chemicals are shown in Table 1) and b) after 2 days of 
373 transplantation at three different sites in Arcachon Bay. Different letters indicate statistical

374 differences $(\mathrm{P}<0.05)$. Results are presented as the mean $( \pm \mathrm{SD})$ of 5 (pesticide mixture) and 4 375 (in situ) independent experiments.

\subsection{Gene expression analysis}

378 Transcriptions of 14 selected genes known to be involved in mitochondrial metabolism, 379 detoxification, antioxidant defenses, biotransformation process, cycle cellular arrest and 380 apoptosis, and DNA damage repair were investigated. The results of the gene expression level 381 analysis are shown in Table 4. In the laboratory exposure study, only 5 genes were found to 382 be downregulated. Genes 12S, cypla, and gadd45 showed comparable levels of 383 downregulation in oyster larvae after exposure to the two lowest (environmental) 384 concentrations of the MIX. In addition, one of the metallothionein genes (mt2) and bax gene 385 were downregulated in oyster larvae after exposure to $8 \mu \mathrm{g} / \mathrm{L}$ of the MIX. In situ approach 386 revealed more affected genes than the laboratory approach and enabled a comparison between 387 the three sites. No differences between the sites were observed at the level of bax, casp3, 388 cypla, gadd45, p53, and sodCu. Importantly, both $\mathrm{C}$ and $\mathrm{J}$ sites had highly induced cat and 389 downregulated gpx and $m t 2$ compared to the site GB. 
391 Table 4 Gene expressions in the oyster larvae a) exposed in the laboratory for $42 \mathrm{~h}$ to three 392 low, environmental concentrations of pesticide mixture (for individual concentrations cf. 393 Table 1) and b) caged for two days at the three sampling sites. Results are shown as fold 394 changes between target and housekeeping genes for a) MIX -laboratory approach or as the 395 ratio between target and GB site for b) In situ approach. Results are presented as the mean $396( \pm$ SD) of 3 (pesticide mixture) and 4 (in situ) independent experiments. Statistically different 397 results are highlighted in bold. $* \mathrm{P}<0.05 ; * * \mathrm{P}<0.01 ; * * * \mathrm{P}<0.001$. Downregulation: fold 398 changes $<1$; upregulation: fold changes $>1$. Statistical differences obtained by nonparametric 399 Kruskal-Wallis except for cat and sodMn, where normality and homoscedasticity conditions 400 were met and thus ANOVA was used.
a) MIX - laboratory approach
b) In situ approach

\begin{tabular}{lccccc}
\hline & $0.32 \mu \mathrm{g} / \mathrm{L}$ & $1.6 \mu \mathrm{g} / \mathrm{L}$ & $8 \mu \mathrm{g} / \mathrm{L}$ & $\mathrm{J}: \mathrm{GB}$ & $\mathrm{C}: \mathrm{GB}$ \\
\cline { 2 - 6 } $12 \mathrm{~S}$ & $\mathbf{0 . 7} \pm \mathbf{0 . 2} * *$ & $\mathbf{0 . 9} \pm \mathbf{0 . 1} *$ & $0.9 \pm 0.2$ & $1.2 \pm 0.5$ & $\mathbf{1 . 3} \pm \mathbf{0 . 2} * *$ \\
bax & $1.0 \pm 0.1$ & $1.0 \pm 0.3$ & $\mathbf{0 . 8} \pm \mathbf{0 . 0} * *$ & $1.0 \pm 0.1$ & $1.0 \pm 0.1$ \\
casp3 & $0.9 \pm 0.1$ & $1.0 \pm 0.1$ & $0.9 \pm 0.1$ & $0.9 \pm 0.3$ & $1.1 \pm 0.1$ \\
cat & $1.0 \pm 0.5$ & $0.7 \pm 0.2$ & $1.3 \pm 0.5$ & $\mathbf{3 . 4} \pm \mathbf{1 . 1} * * *$ & $\mathbf{2 . 7} \pm \mathbf{1 . 2} * * *$ \\
cox1 & $1.5 \pm 0.5$ & $1.0 \pm 0.3$ & $1.1 \pm 0.2$ & $\mathbf{1 . 3} \pm \mathbf{0 . 3} * *$ & $1.2 \pm 0.4$ \\
cyp1a & $\mathbf{0 . 7} \pm \mathbf{0 . 2} * * *$ & $\mathbf{0 . 8} \pm \mathbf{0 . 2} * * *$ & $\mathbf{0 . 9} \pm \mathbf{0 . 1} *$ & $0.9 \pm 0.5$ & $0.8 \pm 0.2$ \\
gadd45 & $\mathbf{0 . 8} \pm \mathbf{0 . 4} *$ & $\mathbf{0 . 7} \pm \mathbf{0 . 1} * * *$ & $\mathbf{0 . 7} \pm \mathbf{0 . 2} * *$ & $1.4 \pm 0.8$ & $1.1 \pm 0.5$ \\
gpx & $1.1 \pm 0.1$ & $0.8 \pm 0.1$ & $1.0 \pm 0.2$ & $\mathbf{0 . 7} \pm \mathbf{0 . 1} * * *$ & $\mathbf{0 . 6} \pm \mathbf{0 . 1} * * *$ \\
mt1 & $1.6 \pm 1.0$ & $1.5 \pm 0.7$ & $1.5 \pm 1.0$ & $1.1 \pm 0.7$ & $\mathbf{0 . 6} \pm \mathbf{0 . 5} * * *$ \\
mt2 & $0.8 \pm 0.4$ & $0.9 \pm 0.4$ & $\mathbf{0 . 7} \pm \mathbf{0 . 3} *$ & $\mathbf{0 . 8} \pm \mathbf{0 . 5} *$ & $\mathbf{0 . 5} \pm \mathbf{0 . 3} * * *$ \\
p53 & $1.5 \pm 1.1$ & $1.8 \pm 1.0$ & $1.5 \pm 0.9$ & $1.0 \pm 0.3$ & $1.1 \pm 0.2$ \\
rad51 & $0.9 \pm 0.2$ & $1.0 \pm 0.2$ & $0.8 \pm 0.2$ & $\mathbf{0 . 8} \pm \mathbf{0 . 2} *$ & $1.0 \pm 0.1$ \\
sodCu & $1.5 \pm 1.0$ & $1.4 \pm 0.9$ & $1.6 \pm 0.5$ & $1.0 \pm 0.4$ & $1.1 \pm 0.3$ \\
sodMn & $1.4 \pm 1.0$ & $1.4 \pm 0.8$ & $1.3 \pm 0.5$ & $1.2 \pm 0.2$ & $\mathbf{1 . 2} \pm \mathbf{0 . 2} *$
\end{tabular}




\section{Discussion}

403

404 GB site, as expected, presents the lowest pesticide concentrations in Arcachon Bay (except for 405 IMI during the installation of the device). However, the differences in concentrations between 406 the three sites were rather low (no more than 3 times higher at $\mathrm{J}$ or $\mathrm{C}$ sites in comparison with 407 GB; cf. Table 3). Interestingly, unlike in previous years, concentrations of MOA and MESA 408 were lower than concentrations of the parent SM or below the limit of detection. During 409 2010-2016, metolachlor with its metabolites was responsible for $79 \%$ of total pesticide 410 concentration on GB site, moreover, the parent compound represented only $5 \%$ of the total 411 concentration of these three molecules (Tapie and Budzinski, 2018). Variations throughout 412 the year were observed with average concentrations between 500 and $1700 \mathrm{ng} / \mathrm{L}$ (sum of the 413 three substances) with the lowest values recorded in autumn. Nevertheless, the average 414 detected concentration in July during 2010-2016 was approx. $800 \mathrm{ng} / \mathrm{L}$ (sum of the three 415 molecules). However, we are not aware of any change in agricultural practices concerning S416 metolachlor consumption in the last ten years. S-metolachlor was still one of the most used 417 herbicides in France during this work and its purchase in France stayed comparable (around 4181.5 tons) in 2012 and 2019 (Veyrac, 2021). The difference in obtained values may be 419 explained by different sample processing (HDPE bottles used in 2010-2016 monitoring 420 instead of glass vials used in this study because of the hydrophobicity of propiconazole and 421 the concentration of samples using solid-phase extraction method instead of lyophilization 422 method used in this study) and compounds were quantified with grab sampling only giving a 423 snap-shot of contaminants present at the exact sampling time. We suggest that it would be 424 best to use a passive sampling method (Tapie et al., 2011) to provide an accurate time integrative estimation taking into account episodic environmental changes (such as accidental 426 spills and meteorological conditions). The coupling of bivalve caging and passive samplers 427 was already successfully used (Turja et al., 2015). Unfortunately, passive samplers like 428 POCIS usually need at least several days of sampling (Brooks et al., 2012), so their suitability 429 for short embryo-larval oyster caging experiments may not be adequate. Although new types 430 of passive samplers with shorter integration periods are currently being developed such as 431 PTFE- EC POCIS for neonicotinoids like imidacloprid sampling (Noro et al., 2020), they 432 were not operational at the time of our study.

433 The effects of the pesticide mixture on the development of oyster embryo-larval stages were 434 evaluated. Whereas no difference was observed between the three sites, even the lowest tested 
concentration of pesticide mixture $(0.32 \mu \mathrm{g} / \mathrm{L})$ in the laboratory approach led to a higher number of malformed larvae or larvae with arrested development. The pesticide concentration measured in situ was lower than the lowest concentration used in the laboratory. Moreover, other unknown beneficial factors in the field may have play a role (oxygenation, ...). Concerning the developmental malformations, the LOEC for the mixture laboratory experiment was the lowest used $\mathrm{C} 1$ concentration. The LOECs for individual compounds were already determined i.e. PRO and IMI $200 \mu \mathrm{g} / \mathrm{L}$ in our previous study (Kuchovská et al., 2021), SM 10 ng/L (Gamain et al., 2016), and MOA and MESA 100 ng/L (Mai et al., 2014). Data on SM, MOA, and MESA embryotoxicity has thus been previously published but additional experiment with these three substances was repeated in this study to compare toxicity with IMI, PRO, and MIX within the same experiment: LOEC of SM, MOA, and MESA was calculated to be $100 \mathrm{ng} / \mathrm{L}$ for SM and MESA and $1000 \mathrm{ng} / \mathrm{L}$ for MOA based on additional experimentation (cf. Supplementary Figure S1). MOA, MESA, and SM are thus probably the main drivers behind the toxicity of the pesticide mixture. Because the $\mathrm{EC}_{50}$ was not achieved for some compounds, the comparison of $\mathrm{EC}_{30}$ indicates that the pesticides in the studied mixture acted rather through additive toxicity without synergistic or antagonistic interactions. Indeed, the $\mathrm{EC}_{30}$ of the mixture was calculated to be $1.44 \mathrm{mg} / \mathrm{L}$ of imidacloprid and the metabolites, and $335 \mu \mathrm{g} / \mathrm{L}$ of S-metolachlor and propiconazole (when divided proportionally between the compounds), while S-metolachlor, MOA, and MESA had $\mathrm{EC}_{30}$ around $10 \mathrm{ng} / \mathrm{L}, 100 \mathrm{ng} / \mathrm{L}$, and between 10 and $100 \mathrm{ng} / \mathrm{L}$, respectively, as visible from figures of Mai et al. (2014). $\mathrm{EC}_{30}$ of imidacloprid and propiconazole were calculated to be 70.50 and $1.26 \mathrm{mg} / \mathrm{L}$, respectively (Kuchovská et al., 2021). The effect of the mixture thus seemed to be slightly attenuated but insufficiently to be classified as antagonism, which is defined by a minimum two-fold difference (Cedergreen, 2014)

No effects were found on the swimming speed or the trajectory paths in this study even though SM (10 and $1000 \mathrm{ng} / \mathrm{L}$ ) decreased the rectilinear trajectories in the study of Gamain $e t$ al. (2020). The rectilinear trajectory is considered as the major one at this developmental stage of the oyster larva, unlike later stages, when helical swimming is the most useful for hunting prey, finding a settlement, or avoiding predators (Maciejewski et al., 2019). Results from this study are in agreement with the previous study reporting no effects on the same endpoints after exposure to IMI (up to $20 \mu \mathrm{g} / \mathrm{L}$ ) and PRO (up to $2 \mu \mathrm{g} / \mathrm{L}$ ) (Kuchovská et al. 2021). To the best of our knowledge, no other behavioral studies with embryo-larval stages of bivalves exposed to pesticides have been conducted. Concerning other embryo-larval stages, 
Rozmánková et al. (2020) evaluated the effects of SM and its metabolites on total distance swam in light/dark locomotor test of zebrafish (Danio rerio) larvae. This study reported no impact by individual substances (up to $300 \mu \mathrm{g} / \mathrm{L}$ ) and also by the mixture of SM, MOA, and MESA (up to $30 \mu \mathrm{g} / \mathrm{L}$ of each substance in the mixture). However, a decrease in spontaneous tail coiling in zebrafish embryo was observed after exposure to SM $(1 \mu \mathrm{g} / \mathrm{L})$ and the mixture ( $1 \mu \mathrm{g} / \mathrm{L}$ of each substance). The in situ study showed an increase in both maximal and average swimming speeds especially at $\mathrm{J}$ site $(428 \pm 63$ and $263 \pm 34 \mu \mathrm{m} / \mathrm{s}$, respectively) in comparison with GB (304 \pm 49 and $187 \pm 43 \mu \mathrm{m} / \mathrm{s}$, respectively), but these differences were not significantly different (summarizing table can be found in Supplemental Table S3). More field campaigns should be carried out to get a complete and more representative picture. In situ results of trajectory paths showed a non-significant decrease in rectilinear paths and an increase in circular and stationary paths of larvae at $\mathbf{J}$ and $\mathrm{C}$ sites in comparison with larvae of the site GB. Moreover, a clear difference is observed between the path results from the site GB $(n=4)$ and in laboratory non-treated controls $(n=16)$ from all the experimentations done during this project (described in this publication and in Kuchovská et al. 2021),. The swimming paths proportions follows: GB: rectilinear - circular - motionless: $55.5 \pm 12.3 \%$ $29.7 \pm 12.4 \%$ - $14.8 \pm 3.77 \%$; laboratory controls: $74.5 \pm 9.29 \%$ - $18.5 \pm 10.9 \%$ $6.91 \pm 2.39 \%$, respectively. This is an interesting finding which should be 1 . explored further in the future to assess if it is a usual proportion of swimming paths of larvae exposed in situ and 2. compared with larvae of the same age exposed in the laboratory to find out if it is a baseline locomotive activity at that age, or 3. if it is a direct effect of the water quality. Gamain et al. (2020) established a link between erratic larval behavior and the presence of developmental malformations. In this study, negative control containing about $17 \%$ of abnormal larvae exhibited predominantly (around $80 \%$ ) rectilinear, normal, trajectories, whereas $100 \mathrm{ng} / \mathrm{L}$ of S-metolachlor induced around $44 \%$ of abnormal larvae with mostly circular trajectories. In the present study, the malformation rate for larvae exposed in situ was comparably less than $20 \%$. Therefore, we can assume that the locomotion patterns of larvae exposed in situ may be a result of a direct effect on the metabolism and energetic reserves of the larvae or of the water quality of Arcachon Bay on the nervous system of oyster larvae. The nervous system is already developing in D-shaped (veliger) larva and is comprised of a compact apical organ with apical cells, dendrites, neurites (Yurchenko et al., 2018).

Concerning the impacts on the molecular level, the MIX of pesticides changed expressions of several genes of oyster larvae exposed in the laboratory. The gene $12 \mathrm{~S}$ was downregulated, 
501 affecting the synthesis of proteins needed for the mitochondrial membrane and, therefore, 502 resulting in a decreased ribosomal activity for creating ATP, which is necessary for cell viability and defense against pollutants (De Silva et al., 2015). The downregulation of the $12 \mathrm{~S}$ gene was also observed in oyster larvae after exposure to $100 \mathrm{ng} / \mathrm{L}$ of metolachlor (Mai et al., 2014) and $200 \mathrm{ng} / \mathrm{L}$ and $2 \mu \mathrm{g} / \mathrm{L}$ of propiconazole (Kuchovská et al., 2021). Both observations were made in higher concentrations of individual pesticides (10 and 20 times, respectively) than those used in the MIX (cf. Table 1) suggesting thus possible synergistic effect of the MIX on the expression of the $12 \mathrm{~S}$ gene. Cytochrome P450 cypla was strongly downregulated as well. On the contrary, exposure to individual pesticides from the MIX (up to $1 \mu \mathrm{g} / \mathrm{L}$ of metolachlor, MOA, and MESA, up to $2 \mu \mathrm{g} / \mathrm{L}$ of PRO, and up to $100 \mu \mathrm{g} / \mathrm{L}$ of IMI) did not induce any alterations in its expression (Kuchovská et al., 2021; Mai et al., 2014). Therefore, possible interaction effects may have occurred among the components of the mixture. Azoles compounds like propiconazole are known to inhibit cytochrome P450 enzymes (monooxygenases). P450 enzymes participate in the detoxification of xenobiotics (Gottardi et al., 2018), such as neonicotinoids like IMI or acetanilides as SM, by displacing the chlorine atom by glutathione (Roberts et al., 1998). This might be an important mechanism of PRO toxicity towards the Pacific oyster. Moreover, the main mechanism of action of azoles towards their target organisms is to inhibit steroidogenesis and thus obstruct the creation of fungal cell membranes. However, it is possible that this mechanism do not affect the Pacific oyster, since its sterols are likely mostly derived from its prey such as microalgae (Knauer et al., 1998).

Gene gadd45, coding for a stress response protein that regulates growth arrest and DNA damage repair, was downregulated in oyster larvae in all laboratory conditions starting with exposure to $0.32 \mu \mathrm{g} / \mathrm{L}$ of MIX. Interestingly, this gene was reported to be upregulated after exposure to $1 \mu \mathrm{g} / \mathrm{L}$ of IMI contrary to the finding of this study, whilst exposure to PRO did not affect this gene (Kuchovská et al., 2021). To the best of our knowledge, the effect of metolachlor and its two metabolites on the expression of gadd45 is not known, as well as any other chloroacetanilide herbicide. The observed downregulation of gadd45 hinders correct regulation of the cell cycle and suggests possible effects on the DNA integrity (E. Tamura et al., 2012). Moreover, the highest tested concentration of MIX ( $8 \mu \mathrm{g} / \mathrm{L})$ downregulated the expressions of bax and $m t 2$. Bax downregulation corroborates the suspected anti-apoptotic effects of the MIX as suggested also by the downregulation of gadd45. The downregulation of $m t 2$, a gene coding for a multifunctional protein regulating metal homeostasis but also ROS 
534 (reactive oxygen species) scavenging (Migliaccio et al., 2020), after exposure to the MIX is in 535 concordance with the downregulation of the same gene after exposure to $1 \mu \mathrm{g} / \mathrm{L}$ of MESA 536 (Mai et al., 2014). However, the exposure to high concentrations (10 and $100 \mu \mathrm{g} / \mathrm{L}$ ) of IMI 537 caused the opposite effect (Kuchovská et al., 2021). Interestingly, no alteration of expression 538 of genes linked to ROS content regulation was observed, whilst the effects of individual 539 substances of the MIX caused contradictory results (Kuchovská et al., 2021; Mai et al., 2014).

540 It should be highlighted, that the MIX exposure in the laboratory was only a partial 541 representation of the complex situation in Arcachon Bay. Although selected pesticides are the most representative ones of their respective classes (herbicides, insecticides, fungicides), the actual environmental pollution of Arcachon Bay is likely more complex including not only other pesticides but also other pollutants as pharmaceuticals, UV filters, trace metals, organotins, etc. (Besse et al., 2019). Consequently, we will not discuss the situation in situ compared to the laboratory but only the differences between the three sites. The strongest effect was seen on the cat gene, coding for catalase, an enzyme located in cytoplasm and peroxisomes and catalyzing the decomposition of $\mathrm{H}_{2} \mathrm{O}_{2}$ into water and oxygen. Both sites ( $\mathrm{J}$ and C) highly induced its expression in comparison with the site GB, thus demonstrating a possible induction of defense mechanism against ROS (Gebicka and Krych-Madej, 2019). This finding agrees with the induction of sodMn (coding for manganese superoxide dismutase), another gene linked to the stress defense, at $\mathrm{C}$ site. On the other hand, downregulation of another ROS linked gene, gpx (coding for glutathione peroxidase), was observed at both sites. This suggests that whilst some antioxidant activities may protect cells against increased ROS production, the mitochondria may be more susceptible to the adverse effects along with the gpx suppression and absence of catalase in mitochondria (Ighodaro and Akinloye, 2018). Metallothionein gene expression $(m t 1, m t 2)$ was strongly downregulated at both sites ( $\mathrm{J}$ and $\mathrm{C}$ ) in comparison with GB site. The downregulation of $m t 1, m t 2$ (along with gpx) generally show lower scavenging and protective capacity of the cells in oysters exposed 560 in sites J and C (Ruttkay-Nedecky et al., 2013; Takahashi, 2015). Genes coxl (upregulated at $561 \mathrm{~J}$ site) and 12S (upregulated at $\mathrm{C}$ site) are both linked to mitochondrial metabolism. Coxl, coding for the enzyme cytochrome c oxidase subunit 1, upregulation suggests increased creation of ATP probably to effectively defend the organism against pollutants (Kadenbach,

564 2018), whilst upregulation of $12 \mathrm{~S}$ indicates increased ribosomal activity in mitochondria or 565 increased number of mitochondria which ultimately also leads to increased energy production 566 (De Silva et al., 2015). Gene rad51, coding for a protein involved in DNA repair, was 
downregulated at $\mathbf{J}$ site, suggesting impairment of the DNA repair process (Laurini et al.,

568 2020). Altogether, several lines of evidence from gene expression analyses indicate that both $569 \mathrm{C}$ and $\mathrm{J}$ sites showed a worse state of oyster larvae. This can be linked to their location in the inner part of the bay and the proximity of the $\mathrm{C}$ site with river Leyre, which is the main entrance of the herbicides into Arcachon Bay.

\section{Conclusion}

574

The present work successfully demonstrated the added value of joining two complementary approaches, i.e. laboratory and in situ to evaluate the sublethal impact of water pollution on Pacific oyster larvae (Magallana gigas). Early life stages were exposed either in the laboratory to environmentally relevant reconstituted pesticide mixture or transplanted in situ in caging devices and exposed in Arcachon Bay. Whereas the laboratory mixture, composed of 5 pesticides, caused developmental toxicity already at the environmental concentration of $0.32 \mu \mathrm{g} / \mathrm{L}$ (corresponding to current concentration in Arcachon Bay in France), it did not impair larval swimming. Several effects caused by environmental concentrations of MIX were found at the molecular level such as downregulation of genes linked to mitochondrial metabolism, biotransformation, growth arrest, and DNA damage repair. Moreover, higher concentration also downregulated genes linked to apoptosis and metal regulation. In situ approach allowed to a comparison of three different sites in Arcachon bay: Grand Banc, Comprian, and Les Jacquets, each of them under different contamination pressure. No differences in larvae swimming or development were observed between sites, however, gene expression analysis revealed a worsened state at both sites Comprian and Les Jacquets in comparison with Grand Banc. At these sites, we have observed possible elevation of oxidative stress, downregulated metallothionein function, and enhanced mitochondrial metabolism. However, the obtained in situ results do not explain the issues with oyster development observed in Arcachon Bay in recent years and further investigation should be carried out. This is the first study that successfully complemented laboratory tests with in situ approach, and for the first time, it investigated the swimming of oyster larvae after in situ caging exposures. 


\section{CRediT authorship contribution statement}

597 Eliška Kuchovská: Conceptualization, Investigation, Validation, Data curation, Formal 598 analysis, Writing - original draft, Funding acquisition. Patrice Gonzalez: Supervision, 599 Funding acquisition, Conceptualization, Writing - review \& editing. Lucie Bláhová: 600 Investigation, Methodology, Validation, Writing - review \& editing. Mathilde Barré: 601 Investigation. Corentin Gouffier: Investigation. Jérôme Cachot: Conceptualization, Writing 602 - review \& editing. Alicia Romero-Ramirez: Software, Writing - review \& editing. Luděk 603 Bláha: Writing - review \& editing, Funding acquisition. Bénédicte Morin: Supervision, 604 Funding acquisition, Conceptualization, Writing - review \& editing.

605

\section{Compliance with ethical standards}

607 This work was done in compliance with the Publishing Ethics policy of Elsevier.

608

609

\section{Acknowledgments}

610 The authors would like to thank especially the sailor Stéphane Bujan for his assistance during 611 the fieldwork in Arcachon Bay. We also thank Christelle Clérandeau for technical assistance 612 with seawater handling, Guillemine Daffe for her advice in the PCR laboratory, and 613 Alexandra Coynel and Pierre-Yves Gourves for copper chemical analyses. This research was 614 supported by funding of Campus France (doctoral scholarship), the research infrastructure 615 project from the Czech Ministry of Education (grant number LM2018121), and the Inter616 municipal Union of Arcachon Bay (SIBA).

\section{Funding}

618 This research was supported by funding of Campus France (doctoral scholarship), the 619 research infrastructure project from the Czech Ministry of Education (grant number 620 LM2018121), and the Inter-municipal Union of Arcachon Bay (SIBA). 


\section{References}

ASTM, 2013. E2122-02 Standard Guide for Conducting In-situ Field Bioassays With Caged Bivalves. West Conshohocken, PA, www.astm.org.

Auby, I., Bost, C.-A., Budzinski, H., Dalloyau, S., Desternes, A., Belles, A., Trut, G., Plus, M., Pere, C., Couzi, L., Feigne, C., Steinmetz, J., 2011. Régression des herbiers de zostères dans le Bassin d' Arcachon : état des lieux et recherche des causes, Ifremer ODE LER Arcachon. Bordeaux.

Auby, I., Maurer, D., 2004. Etude de la reproduction de l'huître creuse dans le Bassin d'Arcachon. Arcachon.

Auby, I., Maurer, D., Connès, C., Barbier, C., Perrière-Rumèbe, M., Rigouin, L., Tournaire, M.-P., 2014. Reproduction de 1 'huître creuse dans le Bassin d'Arcachon Année 2014, Ifremer. Arcachon.

Bayne, B.L., Ahrens, M., Allen, S.K., D’auriac, M.A., Backeljau, T., Beninger, P., Bohn, R., Boudry, P., Davis, J., Green, T., Guo, X., Hedgecock, D., Ibarra, A., Kingsley-Smith, P., Krause, M., Langdon, C., Lapègue, S., Li, C., Manahan, D., Mann, R., Perez-Paralle, L., Powell, E.N., Rawson, P.D., Speiser, D., Sanchez, J.-L., Shumway, S., Wang, H., 2017. The Proposed Dropping of the Genus Crassostrea for All Pacific Cupped Oysters and Its Replacement by a New Genus Magallana: A Dissenting View. J. Shellfish Res. 36, 545547.

Beiras Ricardo, 2018. Theory and Practice of Toxicology, in: Marine Pollution. Elsevier, pp. $215-232$.

Benedicto, J., Andral, B., Martínez-Gómez, C., Guitart, C., Deudero, S., Cento, A., Scarpato, A., Caixach, J., Benbrahim, S., Chouba, L., Boulahdid, M., Galgani, F., 2011. A large scale survey of trace metal levels in coastal waters of the Western Mediterranean basin using caged mussels (Mytilus galloprovincialis). J. Environ. Monit. 13, 1495-1505.

Bertrand, F., 2014. The Arcachon Bay Estuary: A "Collage” of Landscapes, in: Fort, M., André, M.-F. (Eds.), Landscapes and Landforms of France. World Geomorphological Landscapes. Springer, pp. 71-80.

Besse, J.P., Geffard, O., Coquery, M., 2012. Relevance and applicability of active biomonitoring in continental waters under the Water Framework Directive. TrAC - 
653

654

655

656

657

658

659

660

661

662

663

664

665

666

667

668

669

670

671

672

673

674

675

676

677

678

679

680

681

Besse, J.P., Mouret, L., Tapie, N., Dumont, J., Corrales, T., Lemenach, K., Pardon, P., Budzinski, H., Vrignon, S., Jeandenand, S., 2019. REMPAR - Livrable 1.2 - Présence et devenir de micropolluants d'intérêt dans le réseau d'assainissement du Bassin d'Arcachon.

Beyer, J., Green, N.W., Brooks, S., Allan, I.J., Ruus, A., Gomes, T., Bråte, I.L.N., Schøyen, M., 2017. Blue mussels (Mytilus edulis spp.) as sentinel organisms in coastal pollution monitoring: A review. Mar. Environ. Res. 130, 338-365.

Brooks, S., Harman, C., Soto, M., Cancio, I., Glette, T., Marigómez, I., 2012. Integrated coastal monitoring of a gas processing plant using native and caged mussels. Sci. Total Environ. 426, 375-386.

Cao, C., Wang, W.X., 2016. Bioaccumulation and metabolomics responses in oysters Crassostrea hongkongensis impacted by different levels of metal pollution. Environ. Pollut. 216, 156-165.

Cappello, T., Maisano, M., Giannetto, A., Parrino, V., Mauceri, A., Fasulo, S., 2015. Neurotoxicological effects on marine mussel Mytilus galloprovincialis caged at petrochemical contaminated areas (eastern Sicily, Italy): 1H NMR and immunohistochemical assays. Comp. Biochem. Physiol. Part - C Toxicol. Pharmacol. $169,7-15$.

Cedergreen, N., 2014. Quantifying synergy: a systematic review of mixture toxicity studies within environmental toxicology. PLoS One 9, 1-12.

Clara Rebouças Do Amaral, M., De Freitas Rebelo, M., Paulo MacHado Torres, J., Christian Pfeiffer, W., 2005. Bioaccumulation and depuration of $\mathrm{Zn}$ and $\mathrm{Cd}$ in mangrove oysters (Crassostrea rhizophorae, Guilding, 1828) transplanted to and from a contaminated tropical coastal lagoon. Mar. Environ. Res. 59, 277-285.

Cognat, M., Ganthy, F., Auby, I., Barraquand, F., Rigouin, L., Sottolichio, A., 2018. Environmental factors controlling biomass development of seagrass meadows of Zostera noltei after a drastic decline (Arcachon Bay, France). J. Sea Res. 140, 87-104.

De Silva, D., Tu, Y.T., Amunts, A., Fontanesi, F., Barrientos, A., 2015. Mitochondrial ribosome assembly in health and disease. Cell Cycle 14, 2226-2250. 
Devier, M.H., Augagneur, S., Budzinski, H., Le Menach, K., Mora, P., Narbonne, J.F., Garrigues, P., 2005. One-year monitoring survey of organic compounds (PAHs, PCBs, TBT), heavy metals and biomarkers in blue mussels from the Arcachon Bay, France. J. Environ. Monit. 7, 224-240.

Tamura, R. E., de Vasconcellos, J. F., Sarkar, D., Libermann, T. A., Fisher, P. B., Zerbini, L. F., 2012. GADD45 Proteins: Central Players in Tumorigenesis. Curr. Mol. Med. 12, 634651.

EC, 2020. Chemicals Strategy for Sustainability Towards a Toxic-Free Environment. Brussels.

Ewere, E.E., Reichelt-Brushett, A., Benkendorff, K., 2021. Impacts of Neonicotinoids on Molluscs: What We Know and What We Need to Know. Toxics 9, 21.

Ferrari, B.J.D., Geffard, O., Chaumot, A., 2013. In Situ Bioassays in Ecotoxicology, in: Encyclopedia of Aquatic Ecotoxicology. Springer Netherlands, pp. 635-642.

Gamain, P., 2016. Impact des polluants et du changement climatique sur les capacités de reproduction et le développement embryo larvaire de l'huître creuse Crassostrea gigas dans le Bassin d'Arcachon. Université de Bordeaux.

Gamain, P., Cachot, J., Gonzalez, P., Budzinski, H., Gourves, P.-Y., Morin, B., 2017. Do Temporal and Spatial Parameters or Lifestyle of the Pacific Oyster Crasssostrea gigas Affect Pollutant Bioaccumulation, Offspring Development, and Tolerance to Pollutants? Front. Mar. Sci. 4, 58.

Gamain, P., Gonzalez, P., Cachot, J., Pardon, P., Tapie, N., Gourves, P.Y., Budzinski, H., Morin, B., 2016. Combined effects of pollutants and salinity on embryo-larval development of the Pacific oyster, Crassostrea gigas. Mar. Environ. Res. 113, 31-38.

Gamain, P., Roméro-Ramirez, A., Gonzalez, P., Mazzella, N., Gourves, P.-Y., Compan, C., Morin, B., Cachot, J., 2020. Assessment of swimming behavior of the Pacific oyster Dlarvae (Crassostrea gigas) following exposure to model pollutants. Environ. Sci. Pollut. Res. 27, 3675-3685.

Gebicka, L., Krych-Madej, J., 2019. The role of catalases in the prevention/promotion of oxidative stress. J. Inorg. Biochem. 197, 7.

Geffard, O., His, E., Budzinski, H., Seaman, M., Garrigues, P., 2001. Qualité biologique de 
l'eau de mer évaluée in situ par le test embryo-larvaire de Crassostrea gigas et Mytilus galloprovincialis. Comptes Rendus l'Académie des Sci. - Ser. III - Sci. la Vie 324, 1149 1155 .

Glinski, D.A., Purucker, S.T., Van Meter, R.J., Black, M.C., Henderson, W.M., 2018. Analysis of pesticides in surface water, stemflow, and throughfall in an agricultural area in South Georgia, USA. Chemosphere 209, 496-507.

Gottardi, M., Tyzack, J.D., Bender, A., Cedergreen, N., 2018. Can the inhibition of cytochrome P450 in aquatic invertebrates due to azole fungicides be estimated with in silico and in vitro models and extrapolated between species? Aquat. Toxicol. 201, 11-20.

Götz, T., Böger, P., 2004. The Very-Long-Chain Fatty Acid Synthase Is Inhibited by Chloroacetamides. Zeitschrift für Naturforsch. C 59 c, 549-553.

Haynes, D., Mosse, P., Oswald, L., 1995. The use of transplanted cultured mussels (Mytilus edulis) to monitor pollutants along the Ninety Mile Beach, Victoria, Australia- II. Polychlorinated dibenzo-p-dioxins and dibenzofurans. Mar. Pollut. Bull. 30, 834-839.

Hédouin, L., Pringault, O., Bustamante, P., Fichez, R., Warnau, M., 2011. Validation of two tropical marine bivalves as bioindicators of mining contamination in the New Caledonia lagoon: Field transplantation experiments. Water Res. 45, 483-496.

Hutchinson, T.H., Solbé, J., Kloepper-Sams, P.J., 1998. Analysis of the ECETOC Aquatic Toxicity (EAT) database. III - Comparative toxicity of chemical substances to different life stages of aquatic organisms. Chemosphere 36, 129-142.

Ighodaro, O.M., Akinloye, O.A., 2018. First line defence antioxidants-superoxide dismutase (SOD), catalase (CAT) and glutathione peroxidase (GPX): Their fundamental role in the entire antioxidant defence grid. Alexandria J. Med. 54, 287-293.

Jenny, M.J., Walton, W.C., Payton, S.L., Powers, J.M., Findlay, R.H., O’Shields, B., Diggins, K., Pinkerton, M., Porter, D., Crane, D.M., Tapley, J., Cunningham, C., 2016. Transcriptomic evaluation of the American oyster, Crassostrea virginica, deployed during the Deepwater Horizon oil spill: Evidence of an active hydrocarbon response pathway. Mar. Environ. Res. 120, 166-181.

Kadenbach, B., 2018. Regulation of mitochondrial respiration and ATP synthesis via cytochrome c oxidase. Rend. Lincei 29, 421-435. 
Kalkhoff, S.J., Vecchia, A. V, Capel, P.D., Meyer, M.T., 2012. Eleven-Year Trend in Acetanilide Pesticide Degradates in the Iowa River, Iowa. J. Environ. Qual. 41, 15661579.

Knauer, J., Kerr, R.G., Lindley, D., Southgate, P.C., 1998. Sterol metabolism of pacific oyster (Crassostrea gigas) spat. Comp. Biochem. Physiol. - B Biochem. Mol. Biol. 119, 81-84.

Kuchovská, E., Morin, B., López-Cabeza, R., Barré, M., Gouffier, C., Bláhová, L., Cachot, J., Bláha, L., Gonzalez, P., 2021. Comparison of imidacloprid, propiconazole, and nanopropiconazole effects on the development, behavior, and gene expression biomarkers of the Pacific oyster (Magallana gigas). Sci. Total Environ., 764, 142921.

Labbate, M., Delmont, T.O., Le Roux, F., Petton, B., Bruto, M., James, A., Labreuche, Y., Alunno-Bruscia, M., 2015. Crassostrea gigas mortality in France: the usual suspect, a herpes virus, may not be the killer in this polymicrobial opportunistic disease. Front. Microbiol. 6, 10.

Laurini, E., Marson, D., Fermeglia, A., Aulic, S., Fermeglia, M., Pricl, S., 2020. Role of Rad51 and DNA repair in cancer: A molecular perspective. Pharmacol. Ther. 208, 107492.

Lee, J.H., Birch, G.F., 2016. The mismatch of bioaccumulated trace metals $(\mathrm{Cu}, \mathrm{Pb}$ and $\mathrm{Zn})$ in field and transplanted oysters (Saccostrea glomerata) to ambient surficial sediments and suspended particulate matter in a highly urbanised estuary (Sydney estuary, Australia). Environ. Monit. Assess. 188, 1-17.

Lehtonen, K.K., Turja, R., Budzinski, H., Devier, M.H., 2016. An integrated chemicalbiological study using caged mussels (Mytilus trossulus) along a pollution gradient in the Archipelago Sea (SW Finland, Baltic Sea). Mar. Environ. Res. 119, 207-221.

Leverett, D., Thain, J., 2013. Oyster embryo-larval bioassay (revised). Int. Counc. Explor. Sea Tech. Mar. Environ. Sci. 54, 34.

Maciejewski, M.F., Meyer, K.S., Wheeler, J.D., Anderson, E.J., Pittoors, N.C., Mullineaux, L.S., 2019. Helical swimming as an exploratory behavior in competent larvae of the eastern oyster (Crassostrea virginica). J. Exp. Mar. Bio. Ecol. 510, 86-94.

Mai, H., Cachot, J., Clérandeau, C., Martin, C., Mazzela, N., Gonzalez, P., Morin, B., 2020. An environmentally realistic pesticide and copper mixture impacts embryonic 

development and DNA integrity of the Pacific oyster, Crassostrea gigas. Environ. Sci. Pollut. Res. 27, 3600-3611.

Mai, H., Gonzalez, P., Pardon, P., Tapie, N., Budzinski, H., Cachot, J., Morin, B., 2014. Comparative responses of sperm cells and embryos of Pacific oyster (Crassostrea gigas) to exposure to metolachlor and its degradation products. Aquat. Toxicol. 147, 48-56.

Mai, H., Morin, B., Pardon, P., Gonzalez, P., Budzinski, H., Cachot, J., 2013. Environmental concentrations of irgarol, diuron and S-metolachlor induce deleterious effects on gametes and embryos of the Pacific oyster, Crassostrea gigas. Mar. Environ. Res. 89, 1-8.

Matsuda, K., Buckingham, S.D., Kleier, D., Rauh, J.J., Grauso, M., Sattelle, D.B., 2001. Neonicotinoids: insecticides acting on insect nicotinic acetylcholine receptors. Trends Pharmacol. Sci. 22, 573-580.

Meffe, R., de Bustamante, I., 2014. Emerging organic contaminants in surface water and groundwater: A first overview of the situation in Italy. Sci. Total Environ. 481, 280-295.

Migliaccio, V., Lionetti, L., Putti, R., Scudiero, R., 2020. Exposure to Dichlorodiphenyldichloroethylene (DDE) and Metallothionein Levels in Rats Fed with Normocaloric or High-Fat Diet: A Review. Int. J. Mol. Sci. 21, 1903.

Morrissey, C.A., Mineau, P., Devries, J.H., Sanchez-Bayo, F., Liess, M., Cavallaro, M.C., Liber, K., 2015. Neonicotinoid contamination of global surface waters and associated risk to aquatic invertebrates: A review. Environ. Int. 74, 291-303.

NF ISO 17244, 2015. Qualité de l'eau - Détermination de la toxicité d'échantillons aqueux sur le développement embryo-larvaire de l'huître creuse (Crassostrea gigas) et de la moule (Mytilus edulis ou Mytilus galloprovincialis).

Noro, K., Endo, S., Shikano, Y., Banno, A., Yabuki, Y., 2020. Development and Calibration of the Polar Organic Chemical Integrative Sampler (POCIS) for Neonicotinoid Pesticides. Environ. Toxicol. Chem. 39, 1325-1333.

Oliver, R.P., Hewitt, H.G., 2014. Fungicide Performance, in: Fungicides in Crop Protection. CABI, pp. 71-123.

Peng, Y., Fang, W., Krauss, M., Brack, W., Wang, Z., Li, F., Zhang, X., 2018. Screening hundreds of emerging organic pollutants (EOPs) in surface water from the Yangtze River Delta (YRD): Occurrence, distribution, ecological risk. Environ. Pollut. 241, 484-493. 
802

803

804

805

806

807

808

809

810

811

812

813

814

815

816

817

818

819

820

821

822

824

825

826

827

828

829

830

831

Quiniou, F., Damiens, G., Gnassia-Barelli, M., Geffard, A., Mouneyrac, C., Budzinski, H., Roméo, M., 2007. Marine water quality assessment using transplanted oyster larvae. Environ. Int. 33, 27-33.

Rebich, R.A., Coupe, R.H., Thurman, E.M., 2004. Herbicide concentrations in the Mississippi River Basin - The importance of chloroacetanilide herbicide degradates. Sci. Total Environ. 321, 189-199.

Roberts, T.R., Hutson, D.H., Lee, P.W., Nicholls, P.H., Plimmer, J.R., 1998. Metabolic Pathways of Agrochemicals Part 1: Herbicides and Plant Growth Regulators, in: Roberts, T.R. (Ed.), Journal of Chemical Information and Modeling. The Royal Society of Chemistry, Cambridge, pp. 179-218.

Rozmánková, E., Pípal, M., Bláhová, L., Njattuvetty Chandran, N., Morin, B., Gonzalez, P., Bláha, L., 2020. Environmentally relevant mixture of S-metolachlor and its two metabolites affects thyroid metabolism in zebrafish embryos. Aquat. Toxicol. 221, 105444.

Ruttkay-Nedecky, B., Nejdl, L., Gumulec, J., Zitka, O., Masarik, M., Eckschlager, T., Stiborova, M., Adam, V., Kizek, R., 2013. The role of metallothionein in oxidative stress. Int. J. Mol. Sci. 14, 6044-6066.

Sokal, R.R., Rohlf, F.J., 2012. Biometry: The principles and practice of statistics in biological research, 4th ed. Peter Marshall, New York.

Stachowski-Haberkorn, S., Quiniou, F., Nedelec, M., Robert, R., Limon, G., De La Broise, D., 2008. In-situ microcosms, a tool for assessment of pesticide impacts on oyster spat (Crassostrea gigas). Ecotoxicology 17, 235-245.

Starner, K., Goh, K.S., 2012. Detections of the neonicotinoid insecticide imidacloprid in surface waters of three agricultural regions of California, USA, 2010-2011. Bull. Environ. Contam. Toxicol. 88, 316-321.

Takahashi, S., 2015. Positive and negative regulators of the metallothionein gene (Review). Mol. Med. Rep. 12, 795-799.

Tapie, N., Budzinski, H., 2018. Quantification de la présence dans les eaux bilan de 2010 à 2016. Rapport du Reseau Pesticides du Bassin d'Arcachon (REPAR) janvier 2018.

Tapie, N., Devier, M.H., Soulier, C., Creusot, N., Le Menach, K., Aït-Aïssa, S., Vrana, B., 
Budzinski, H., 2011. Passive samplers for chemical substance monitoring and associated toxicity assessment in water. Water Sci. Technol. 63, 2418-2426.

Troost, K., 2010. Causes and effects of a highly successful marine invasion: Case-study of the introduced Pacific oyster Crassostrea gigas in continental NW European estuaries. J. Sea Res. 64, 145-165.

Turja, R., Lehtonen, K.K., Meierjohann, A., Brozinski, J.M., Vahtera, E., Soirinsuo, A., Sokolov, A., Snoeijs, P., Budzinski, H., Devier, M.H., Peluhet, L., Pääkkönen, J.P., Viitasalo, M., Kronberg, L., 2015. The mussel caging approach in assessing biological effects of wastewater treatment plant discharges in the Gulf of Finland (Baltic Sea). Mar. Pollut. Bull. 97, 135-149.

Van Dijk, T.C., Van Staalduinen, M.A., Van der Sluijs, J.P., 2013. Macro-Invertebrate Decline in Surface Water Polluted with Imidacloprid. PLoS One 8, e62374.

Veyrac Christine, 2021. Données de vente de produits phytopharmaceutiques 2011 à 2019. Agreste, 1-12. Visited online 1.5.2021 at https://agreste.agriculture.gouv.fr/agresteweb/download/publication/publie/Chd2104/cd2021-4_VentePPP.pdf

Yurchenko, O. V., Skiteva, O.I., Voronezhskaya, E.E., Dyachuk, V.A., 2018. Nervous system development in the Pacific oyster, Crassostrea gigas (Mollusca: Bivalvia). Front. Zool. 15,21 . 
853 Supplementary Table S1:

854 Concentrations of pesticides of interest detected on multiple sites in Arcachon Bay in the 855 years 2010-2014. N=669 for each pesticide. Concentrations were calculated according to the 856 data of Tapie et al., (2018).

PRO IMI Metolachlor MOA MESA

\begin{tabular}{lccccc}
\cline { 2 - 6 } Limit of quantification (ng/L) & 1 & 1 & 0.5 & 3 & 2 \\
\hline Samples with detected substance (\%) & 20.7 & 34.8 & 90.3 & 87.6 & 88.0 \\
\hline Average concentration in all samples & \multirow{2}{*}{0.7} & 2.6 & 31.9 & 163.5 & 117.6 \\
(ng/L) & & & & & \\
\hline Average concentration in samples with & \multirow{2}{*}{3.1} & 7.6 & 35.4 & 186.9 & 133.8 \\
detected substance (ng/L) & & & & & \\
\hline Maximal concentration (ng/L) & $\mathbf{2 9 . 1}$ & $\mathbf{1 7 3 . 6}$ & $\mathbf{1 6 9 5 . 9}$ & $\mathbf{1 6 0 9 . 9}$ & $\mathbf{1 0 5 9 . 2}$
\end{tabular}

858

859

860 


\section{Supplementary material S1:}

862

863

864

865

866

867

868

869

870

871

872

873

874

875

876

877

878

879

880

881

882

883

884

\section{LC-MS/MS analysis of pesticides}

The analysis was performed with a Waters LC chromatograph (Waters, Manchester, U.K.) and the chromatographic separation was achieved using a column Acquity BEH C18 of $100 \mathrm{x}$ $2.1 \mathrm{~mm}$ ID and $1.7 \mu \mathrm{m}$ particle size. A gradient elution method was set with phase A $(0.1 \%$ formic acid in water) and phase B ( $0.1 \%$ formic acid in acetonitrile). The gradient elution started with $20 \% \mathrm{~B}$, increased to $90 \%$ B over 9 min, followed by 3 min of washing (100\% $\mathrm{B}$, then decreased to $20 \% \mathrm{~B}$ and held for $4 \mathrm{~min}$ to equilibrate the system before the next injection. The flow rate was set at $0.3 \mathrm{~mL} / \mathrm{min}$ and the injection volume of samples in $20 \%$ of acetonitrile at $8 \mu \mathrm{L}$. The column and sample temperatures were set at $35^{\circ} \mathrm{C}$ and $10^{\circ} \mathrm{C}$, respectively.

Detection was performed on a Xevo TQ-S quadrupole mass spectrometer (Waters Manchester, U.K.) and analytes after ESI ionisation were detected in positive ion mode using tandem mass spectrometry. The following $\mathrm{m} / \mathrm{z}$ transitions were monitored, for imidacloprid: $m / z 256.1>175.0$, (quant.: cone voltage 25V; collision energy 20V) and $m / z 256.1>209.0$ (qual.: cone voltage 25V; collision energy $12 \mathrm{~V}$ ); for propiconazole: $\mathrm{m} / z 342.1>159.0$ (quant.: cone voltage $42 \mathrm{~V}$; collision energy $30 \mathrm{~V}$ ) and $\mathrm{m} / \mathrm{z} 342.1>69.0$ (qual.: cone voltage $42 \mathrm{~V}$; collision energy $15 \mathrm{~V}$ ); for imidacloprid D4: $\mathrm{m} / z$. $260.1>213.0$ (quant.: cone voltage $25 \mathrm{~V}$; collision energy $12 \mathrm{~V}$ ); for tebuconazole D6: $\mathrm{m} / z$ 314.3 > 72.1 (quant.: cone voltage 35 V; collision energy $20 \mathrm{~V}$ ); for S-metolachlor: $\mathrm{m} / \mathrm{z} 284.1>176.1$, (quant.: cone voltage 30V; collision energy 25V) and $\mathrm{m} / z 284.1>252.1$ (qual.: cone voltage 30V; collision energy $15 \mathrm{~V}$ ); for metolachlor OA: $\mathrm{m} / \mathrm{z} 280.3>146.2$, (quant.: cone voltage $20 \mathrm{~V}$; collision energy $25 \mathrm{~V}$ ); $\mathrm{m} / \mathrm{z}$ $280.3>119.0$ (qual.: cone voltage 20V; collision energy $30 \mathrm{~V}$ ) and $\mathrm{m} / z 280.3>131.0$ (qual.: cone voltage 20V; collision energy $30 \mathrm{~V}$ ); for metolachlor ESA: $m / z 330.4$ > 160.2, (quant.: 
cone voltage $25 \mathrm{~V}$; collision energy $30 \mathrm{~V}$ ); $\mathrm{m} / \mathrm{z} 330.4>132.1$ (qual.: cone voltage 25V;

886 collision energy $50 \mathrm{~V}$ ) ); $m / z 330.4>145.5$ (qual.: cone voltage $25 \mathrm{~V}$; collision energy $50 \mathrm{~V}$ )

887 and $m / z$ 330.4 > 174.1 (qual.: cone voltage 25V; collision energy $35 \mathrm{~V}$ ). The capillary voltage

888 was set at $3 \mathrm{kV}$ and the cone, desolvation and collision gas flows were set at $150(\mathrm{~L} / \mathrm{h}), 700$

$889(\mathrm{~L} / \mathrm{h})$ and $0.15(\mathrm{~mL} / \mathrm{min})$, respectively. The source and desolvation temperature were set at

$890150^{\circ} \mathrm{C}$ and $400^{\circ} \mathrm{C}$, respectively. Data were processed by MassLynxTM software (Manchester,

891 U.K.). The limit of detection ( $\mathrm{LOD}$, signal to noise ratio $\mathrm{S} / \mathrm{N}>3$ ) for imidacloprid,

892 propiconazole, S-metolachlor, metolachlor OA, and metolachlor ESA were 0.02, 0.005,

$8930.005,0.05$, and $0.05 \mu \mathrm{g} / \mathrm{L}$, respectively. The limit of quantification (LOQ, signal to noise

894 ratio $\mathrm{S} / \mathrm{N}>10$ ) for imidacloprid, propiconazole, S-metolachlor, metolachlor OA, and

895 metolachlor ESA were $0.05,0.01,0.01,0.1$ and $0.1 \mu \mathrm{g} / \mathrm{L}$, respectively. The analytes were

896 quantified using external calibration $(0.01-50 \mu \mathrm{g} / \mathrm{L}$ in $20 \%$ of acetonitrile $)$ and normalized

897 with internal deuterium labelled standards (imidacloprid D4 for imidacloprid, MOA and

898 MESA and tebuconazole D6 for SM and propiconazole). 
901 Sum of abnormal oyster larvae (arrested development and different malformation types) after

90230 hours of exposure to increasing concentrations of SM, MOA, and MESA. Different letters

903 indicate statistical differences between variables $(\mathrm{P}<0.05)$. Results are presented as the mean 904 of 3 independent experiments \pm SD.

905

906

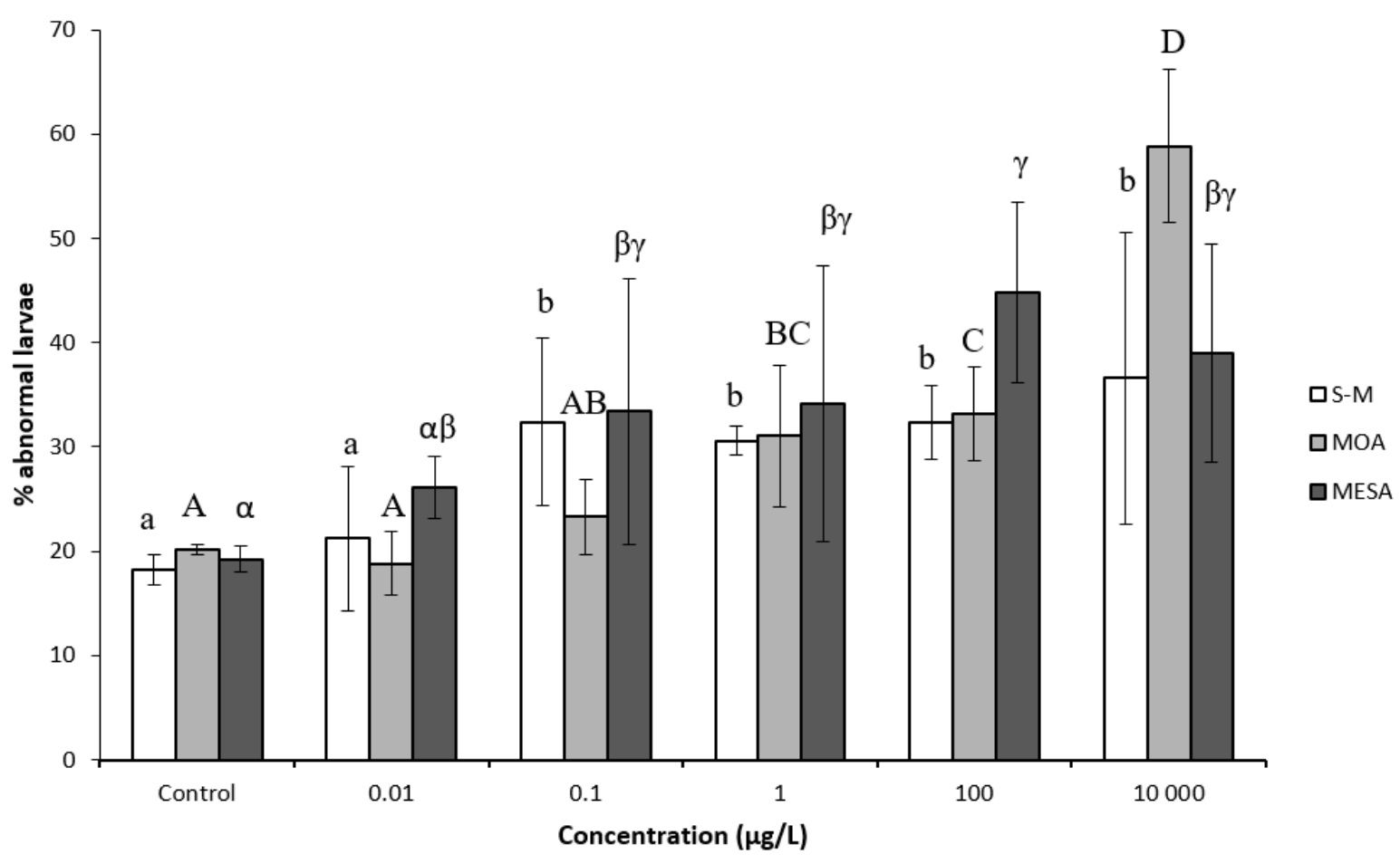

907 
909 Supplementary Table S2:

910 Swimming speed $(\mu \mathrm{m} / \mathrm{s})$ observed in oyster larvae after 2 days of transplantation at three

911 different sites in Arcachon Bay. Results are presented as the mean of 4 independent 912 experiments \pm SD.

913

\begin{tabular}{cc|cc} 
& & \multicolumn{2}{|c}{ Speed $(\mu \mathrm{m} / \mathrm{s})$} \\
& Sampling site & maximal & average \\
\hline Grand Banc & $304 \pm 49$ & $187 \pm 43$ \\
Les Jacquets & $428 \pm 63$ & $263 \pm 34$ \\
$914 \quad$ Comprian & $341 \pm 74$ & $204 \pm 43$
\end{tabular}

915 